\title{
Nanoscale
}

Check for updates

Cite this: Nanoscale, 2021, 13, 18865

\section{Precursor chemistry of metal nitride nanocrystals}

\author{
Mahsa Parvizian (D) and Jonathan De Roo (D) *
}

\begin{abstract}
Metal nitride nanocrystals are a versatile class of nanomaterials. Depending on their chemical composition, the optical properties vary from those of traditional semiconductor nanocrystals (called quantum dots) to more metallic character (featuring a plasmon resonance). However, the synthesis of colloidal metal nitride nanocrystals is challenging since the underlying precursor chemistry is much less developed compared to the chemistry of metal, metal chalcogenide or metal phosphide nanocrystals. Here, we review chemical approaches that lead (or could lead) to the formation of colloidally stable metal nitride nanocrystals. By systematically comparing different synthetic approaches, we uncover trends and gain insight into the chemistry of these challenging materials. We also discuss and critically evaluate the plausibility of certain suggested mechanisms. This review is meant as a guide for the further development of colloidal nitride nanocrystals.
\end{abstract}

\section{Introduction}

Various nanomaterials show size-dependent properties, e.g., magnetic, electrical, and optical properties that cannot be achieved in the bulk material. Therefore, the synthesis of uniform nanocrystals (NC) with controlled size and shape has been attracting a lot of attention. ${ }^{1}$ While atomic precision is still more an aspiration than a reality in nanocrystal science, ${ }^{2}$ it is imperative to produce colloids with narrow size distri-

Department of Chemistry, University of Basel, Basel, Switzerland.

E-mail: Jonathan.DeRoo@unibas.ch; Tel: +41612071046

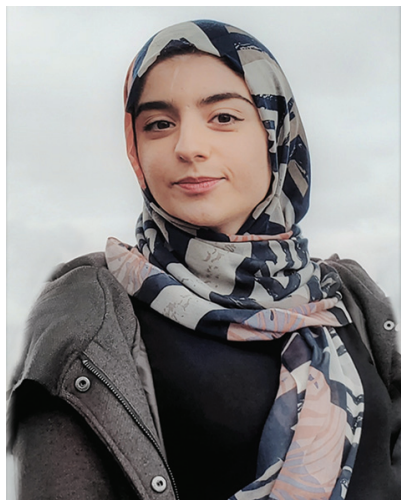

Mahsa Parvizian completed her Bachelor and Master in chemistry at the University of Paris. In 2020 she started her PhD under the supervision of Prof. De Roo at the University of Basel. Her research focuses on the synthesis of metal nitride nanocrystals and their reaction mechanism. butions (low polydispersity) to allow the study of size dependent properties. ${ }^{3}$ One of the most well-known phenomena is the tunable luminescence of quantum dots (QDs), covering the entire UV-VIS-NIR spectrum depending on the QD size and chemical composition. ${ }^{4}$

Ligand-assisted, wet chemical synthesis has provided the necessary control over nanocrystal size and shape. ${ }^{5}$ However, it is a complex process, combining metal-organic chemistry, inorganic crystallization and surface chemistry to yield an organic/ inorganic hybrid object that is colloidally stable. The precursor conversion mechanism of many metals, metal chalcogenide, metal phosphide and metal halide NCs has been elucidated. ${ }^{6-9}$

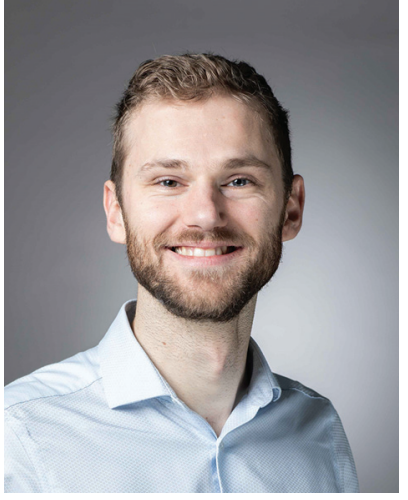

Jonathan De Roo
Dr Jonathan De Roo studied chemistry at Ghent University and obtained his PhD on the surface chemistry of metal oxide nanocrystals in 2016. During his PhD, he was also three months at ETH Zurich to study the surface of $\mathrm{CsPbBr}$ nanocrystals. He completed a postdoc at Columbia University, working on crystallization mechanisms and the design of new ligands. In 2019, he joined the University of Basel as Tenure Track Assistant Professor. His research team focuses on mechanistic aspects in the synthesis of ceramic nanocrystals and atomically precise oxo-clusters. Both precursor conversion and crystallization mechanism are studied. 
and also their surface chemistry is increasingly better understood. ${ }^{10-16}$ The crystallization mechanism (i.e., nucleation and growth) causes more discussion in the literature. ${ }^{17,18}$ Approaches based on classical nucleation theory are at odds with the Finke-Watzky based mechanisms. ${ }^{19,20}$ Recent evidence shows that many NCs do not nucleate via a burst nucleation event, but rather that nucleation is a continuous process. ${ }^{21-23}$ Continuous nucleation does not necessarily lead to polydisperse ensembles because small NCs grow faster than larger NCs, allowing the newly formed NCs to catch up with the growing NC population. ${ }^{22-25}$ Even without a comprehensive framework for NC crystallization, chemists have been able to adjust the final NCs size by controlling the precursor conversion rate. ${ }^{26}$ The three aspects of colloidal synthesis (precursor conversion, crystallization and surface chemistry) are interdependent. An additional, often neglected parameter is the solvent. During high temperature nanocrystal synthesis, certain popular solvents decompose or polymerize, forming products that compromise the purity of the final NCs. ${ }^{27,28}$ Moreover, the purity of the ligand can considerably influence the solubility of the starting precursors and provide a better capping of the final $\mathrm{NCs}^{29}$

While metal, metal chalcogenide and metal halide NCs are well studied, the metal pnictides have received less attention, with the exception of metal phosphides. ${ }^{9,30-33}$ Metal nitrides in particular are a versatile class of nanomaterials but their synthesis is not well developed. One difficulty is the higher

Table 1 Standard free energies of formation $\left(\mathrm{kJ} \mathrm{mol}^{-1}\right)$ for selected oxides and nitrides at room temperature ${ }^{38}$

\begin{tabular}{lllr}
\hline Oxides & $\Delta G_{\mathrm{f}}^{\circ}$ & Nitrides & \multicolumn{1}{c}{$\Delta G_{\mathrm{f}}^{\circ}$} \\
\hline $\mathrm{TiO}_{2}$ & -891.2 & $\mathrm{TiN}$ & -309.2 \\
$\mathrm{ZrO}_{2}$ & -1042 & $\mathrm{ZrN}$ & -336.8 \\
$\mathrm{MnO}_{2}$ & -464.4 & $\mathrm{Mn}_{3} \mathrm{~N}_{2}$ & -146.4 \\
$\mathrm{Fe}_{2} \mathrm{O}_{3}$ & -744.8 & $\mathrm{Fe}_{2} \mathrm{~N}$ & +12.6 \\
$\mathrm{CoO}$ & -213.8 & $\mathrm{Co}_{3} \mathrm{~N}$ & +8.4 \\
$\mathrm{CuO}$ & -128.4 & $\mathrm{Cu}_{3} \mathrm{~N}$ & +74.5 \\
$\mathrm{ZnO}$ & -318.4 & $\mathrm{Zn}_{3} \mathrm{~N}_{2}$ & -20.9
\end{tabular}

(a)

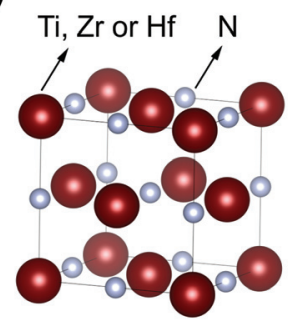

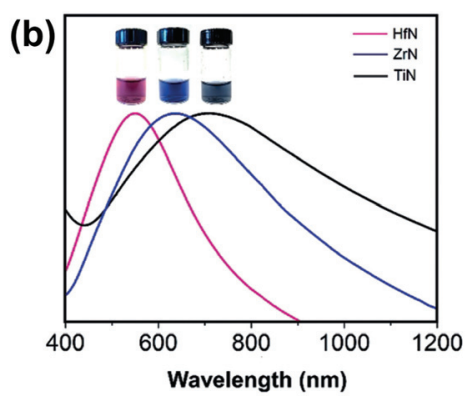

Fig. 1 (a) Crystal structure of group 4 metal nitride. The metal is represented in purple and the nitrogen atom in grey. Structures plotted using VESTA. ${ }^{48}$ Cif file obtained from ref. 49-51 (b) Absorption spectra of aqueous dispersions of $\mathrm{TiN}, \mathrm{ZrN}$, and $\mathrm{HfN} \mathrm{NCs}$. The inset shows a photograph of the NCs dispersed in water. Reprinted from ref. 40 with permission from John Wiley and Sons, Copyright 2019. thermodynamic stability of the oxides, compared to the nitrides (see Table 1). One can rationalize the lower standard formation free energy for nitrides because of the high bond enthalpy of dinitrogen $\left(941 \mathrm{~kJ} \mathrm{~mol}^{-1}\right)$ versus dioxygen $(500 \mathrm{~kJ}$ $\left.\mathrm{mol}^{-1}\right) \cdot{ }^{34,35}$ Another factor is the lower ionic character of metal nitrides since the enthalpy of formation of $\mathrm{N}^{3-}$ is much higher than for $\mathrm{O}^{2-}\left(2300 \mathrm{~kJ} \mathrm{~mol}^{-1}\right.$ versus $\left.700 \mathrm{~kJ} \mathrm{~mol}^{-1}\right) .{ }^{36}$ Only AlN and alkali(ne earth) metal nitrides are regarded as saline nitrides and they react quickly with water, releasing ammonia. ${ }^{37}$ On the other hand, boron and silicon nitride are almost purely covalent compounds with high stability. ${ }^{37}$ Transition metals like titanium form interstitial nitrides with extremely high chemical, thermal and mechanical stability. ${ }^{37}$ TiN has the fcc structure of metallic titanium with interstitial nitrogen atoms in the octahedral holes (Fig. 1). Given the above considerations, it is no surprise that metal nitride synthesis is generally carried out at a high temperature and with nitrogen precursors that are more reactive than molecular nitrogen.

Here, we review the existing synthetic strategies that lead to metal nitride NCs, with a focus on the chemical conversion reactions. A broader review on nitride nanomaterials, including porous and 2D materials can be found elsewhere. ${ }^{39}$ We target predominantly wet chemical syntheses and colloidally stable nanocrystal products. Other methods such as gas phase or solid state synthesis are only included when informative. We do not discuss nitride NCs of the alkali metals or alkaline earth metals since there are no synthetic procedures for nanocrystals available and they are extremely sensitive towards humidity, rendering them less technologically interesting. We will go systematically through the periodic system and discuss the nitrides per group, starting with group 4 and ending with group 13.

\section{Group 4 metal nitrides}

Group 4 transition metal nitrides have a high melting point, a high chemical stability and excellent corrosion resistance. TiN, $\mathrm{ZrN}$ and $\mathrm{HfN}$ have a cubic crystal structure ( $F m \overline{3} m$ space group) with a lattice constant of $4.239 \AA$, $4.585 \AA$, and $4.510 \AA$ A respectively, see Fig. 1. Their NCs exhibit a localized surface plasmon resonance (LSPR) in the visible region ( $\mathrm{HfN}$ and $\mathrm{ZrN}$ ) or in the near infrared regime (TiN), see Fig. $1 .^{40}$ The plasmonic response translates in a highly efficient conversion of sunlight into heat, an effect that has been used for water evaporation and desalination. ${ }^{41-44}$ The position of the LSPR of TiN in the infrared region makes it suitable for photothermal therapies or plasmon-induced photocatalysis. ${ }^{45}$ Given the optical properties of the group 4 metal nitrides, they are an attractive alternative for gold NCs. Furthermore, they exhibit interesting catalytic properties. ZrN NCs possess excellent activity and long-term stability (superior to platinum) as catalysts for the electrochemical oxygen reduction reaction (ORR). ${ }^{46}$ Also HfN NPs are catalytically active for the oxygen evolution reaction (OER). ${ }^{47}$ 
In 1988, TiN films were prepared using atomic layer epitaxy at $500{ }^{\circ} \mathrm{C} ; \mathrm{TiCl}_{4}$ precursor was pulsed into a reactor with gaseous ammonia. ${ }^{52}$ The colour depends on the stoichiometry of the film. For $40 \% \mathrm{~N}$ a golden yellow color is observed while for $50 \%$ a dark violet is obtained. Alternatively, $\mathrm{Ti}\left(\mathrm{NMe}_{2}\right)_{4}$ is reacted with ammonia. Similar strategies apply to $\mathrm{ZrN}$ and HfN. An extensive account of customized precursors for Chemical Vapour Deposition (CVD) of the group 4 nitrides is reviewed elsewhere. ${ }^{53}$

\subsection{Non-thermal plasma synthesis}

In 2017, powders of TiN were synthesized in a non-thermal plasma reactor (Fig. 2) from gaseous $\mathrm{TiCl}_{4}$ and ammonia. ${ }^{54}$

$$
6 \mathrm{TiCl}_{4}+8 \mathrm{NH}_{3} \rightarrow 6 \mathrm{TiN}+\mathrm{N}_{2}+24 \mathrm{HCl}
$$

The particle size is tuned from 3 to $8 \mathrm{~nm}$ by decreasing the flow rate of ammonia. The smaller particles are more oxidized than the bigger particles, but all show a plasmon resonance between 800 and $1000 \mathrm{~nm}$. One can obtain $\mathrm{ZrN}$ nanocrystals in a similar fashion using $\mathrm{ZrCl}_{4}$ and $\mathrm{NH}_{3}$ as the precursors. ${ }^{56}$ After synthesis, the powders need to be heated at $200{ }^{\circ} \mathrm{C}$ in an Ar atmosphere to remove the ammonium salt by-products. To avoid this last step, $\mathrm{TiCl}_{4}$ was later replaced with tetrakis(dimethylamido) titanium $\left(\mathrm{Ti}\left(\mathrm{NMe}_{2}\right)_{4}\right){ }^{55}$

$$
6 \mathrm{Ti}\left(\mathrm{NMe}_{2}\right)_{4}+8 \mathrm{NH}_{3} \rightarrow 6 \mathrm{TiN}+\mathrm{N}_{2}+24 \mathrm{HNMe}_{2}
$$

Also here, the particles are 6-8 $\mathrm{nm}$ in size (Fig. 3) and have a well-defined plasmon resonance (around $800 \mathrm{~nm}$ ). However, the particles are not monocrystalline (consisting of 2-3 nm crystallites) and contain a considerable amount of carbon.

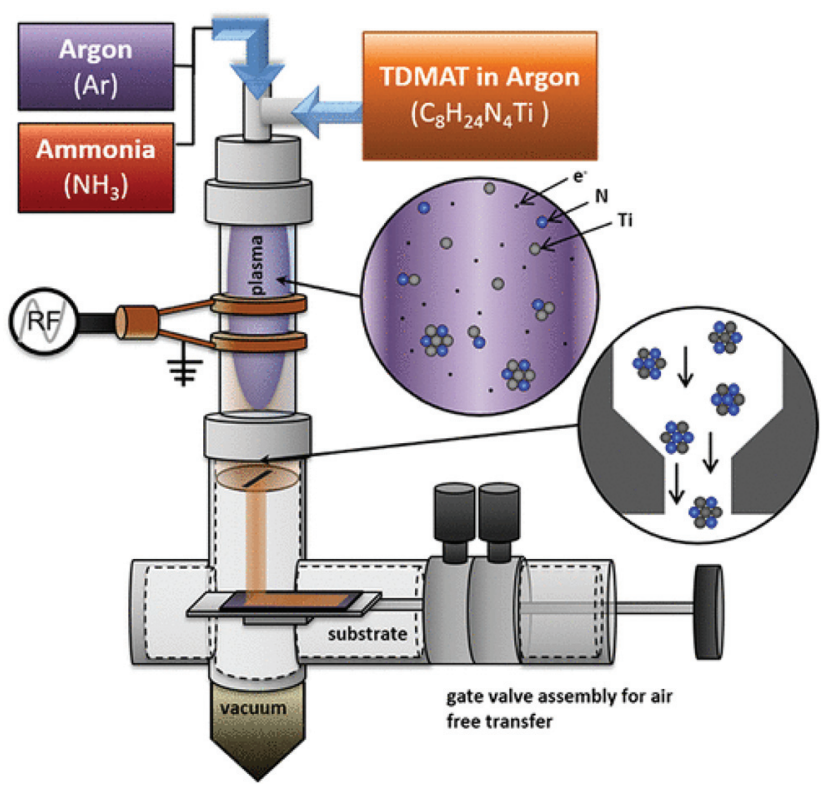

Fig. 2 Diagram of the nonthermal plasma apparatus for TiN NCs synthesis. Reprinted with permission from ref. 55. Copyright 2018 American Chemical Society.
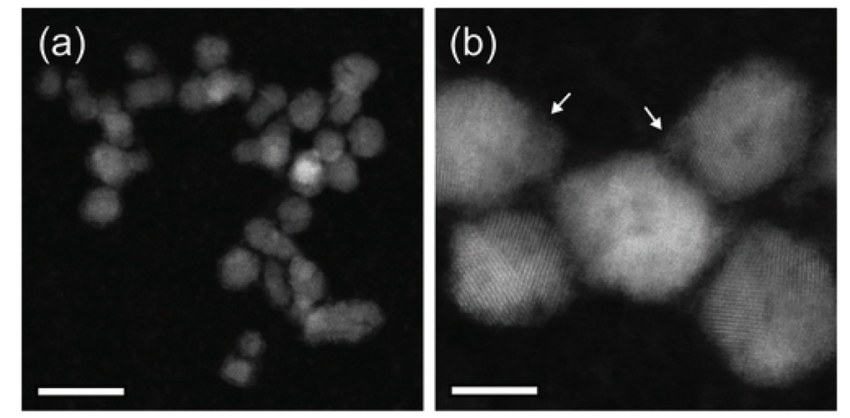

Fig. 3 High-angle annular dark-field scanning transmission electron microscopy (HAADF-STEM) images of the obtained TiN NCs via nonthermal plasma synthesis. Scale bars are (a) $20 \mathrm{~nm}$ and (b) $5 \mathrm{~nm}$. Reprinted with permission from ref. 55. Copyright 2018 American Chemical Society.

\subsection{Solution chemistry of titanium amido and imido complexes}

In solution, $\mathrm{TiCl}_{4}$ reacts with tert-butylamine to the mixed chloro amido complex 1 , see Fig. $4 .^{57} 1$ has been used as a single source precursor for the CVD deposition of TiN. When 1 is reacted with triphenylphosphine oxide, 2 is formed (Fig. 4), which does not convert to TiN during CVD. Complex $\mathbf{1}$ is unstable at room temperature and slowly looses tert-butylamine, probably forming an imido species. This is supported by the formation of the monomeric tert-butylimido complex 3 by the addition of tert-butylpyridine as neutral Lewis base (Fig. 4). ${ }^{58}$

When $\operatorname{Ti}\left(\mathrm{NMe}_{2}\right)_{4}$ is treated with primary amines such as $n$-propylamine, $n$-octylamine or tert-butylamine, transamination occurs. ${ }^{59-61}$ Subsequently, the primary amido group selfcondenses and thus forms alkylimido bridges, see Fig. 5. The rate of transamination and condensation is clearly dependent on the steric hindrance between the alkyl groups of the amine

$$
\mathrm{TiCl}_{4} \underset{-2{ }^{t} \mathrm{BuNH}{ }_{3} \mathrm{Cl}}{\stackrel{+}{+}{ }^{t} \mathrm{BuNH}_{2}} \longrightarrow \mathrm{TiCl}_{2}\left(\mathrm{NH}^{t} \mathrm{Bu}\right)_{2} \cdot 2^{t} \mathrm{BuNH}_{2}
$$

(3)

Fig. 4 Reactions of titanium chloride with tertbutylamine and thiphenylphosphine oxide or tertbutylpyridine.

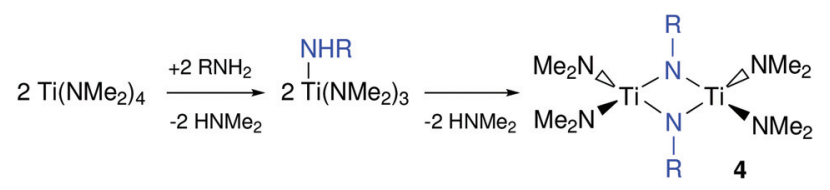

Fig. 5 Transamination followed by self-condensation of primary metal amide group. 
since it proceeds swiftly at room temperature for $n$-propylamine while tert-butylamine only forms the condensed product at $100{ }^{\circ} \mathrm{C} .{ }^{61}$ When using an excess of primary amine, a polymeric, insoluble product is obtained. ${ }^{60}$ However, sols can be formed in tetrahydrofurane (THF) by controlling the amine to titanium stoichiometry. These sols were then used to coat silica via dip-coating and $\mathrm{Ti}(\mathrm{C}, \mathrm{N})$ and $\mathrm{TiN}$ were obtained upon pyrolysis at high temperature (minimum $800{ }^{\circ} \mathrm{C}$ ) under nitrogen or ammonia atmosphere respectively. ${ }^{62}$

Upon addition of one equivalent of primary amine to $\mathrm{Ti}$ $\left(\mathrm{NMe}_{2}\right)_{4}$, the dimer 4 is formed, which can rearrange to a monomeric imido species by coordination of a Lewis base. Addition of two equivalents of trimethylsilylchloride to the latter complex yields the dichloroimido complex. ${ }^{61,63}$ The same product can be made by the addition of a primary amine to $\mathrm{Ti}\left(\mathrm{NMe}_{2}\right)_{2} \mathrm{Cl}_{2}{ }^{64}$ Although most of the above titanium complexes have not been used so far to synthesize TiN NCs, they serve as valuable inspiration for future synthetic development and grant insight in the precursors chemistry of titanium and the rest of the group 4 .

Recently, titanium chloride was reacted with potassium amide in pyridine at $300{ }^{\circ} \mathrm{C} .{ }^{65}$ While the TEM image showed an isolated TiN nanocrystal of $5 \mathrm{~nm}$, the XRD pattern was too broad to be consistent with a large ensemble of $5 \mathrm{~nm}$ crystals. Indeed, another TEM image clearly shows aggregated particles in an amorphous matrix.

\subsection{Synthesis of group 4 nitride powders from the group 4 oxides}

TiN NCs were obtained by Fischer $e t$ al. by using a mesoporous graphitic carbon nitride $\left(\mathrm{mpg}-\mathrm{C}_{3} \mathrm{~N}_{4}\right)$ as both the confinement and nitrogen source. ${ }^{66}$ In this strategy, amorphous $\mathrm{TiO}_{2}$ (confined in the pores) is first prepared via a sol-gel procedure starting from $\mathrm{TiCl}_{4}$ in ethanol. In a second step, this composite product is heated to $800{ }^{\circ} \mathrm{C}$ under inert atmosphere or in sealed quartz ampoules. The confined metal oxide is transformed into pure TiN while the $\mathrm{mpg}-\mathrm{C}_{3} \mathrm{~N}_{4}$ is decomposed, see Fig. 6. The size of the final TiN NCs can be slightly adjusted (5.6 $\mathrm{nm}$ to $7.1 \mathrm{~nm}$ ) by controlling either the pores of the start-

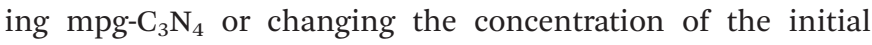
$\mathrm{TiCl}_{4}$ precursor (filling rate). However, the resulting NCs are strongly aggregated. ${ }^{66}$

In 2007, Buha et al. investigated the thermal transformation of pre-synthesized anatase $\mathrm{TiO}_{2} \mathrm{NCs}$ into nanocrystalline TiN by using cyanamide or urea as a nitrogen source at $800{ }^{\circ} \mathrm{C}$ under nitrogen atmosphere. ${ }^{67}$ Complete transformation is achieved when starting from $5 \mathrm{~nm}$ titania while with 10 and $20 \mathrm{~nm}$ titania, anatase impurities are still present. This reflects the solid state nature of the approach. When using a high excess of cyanamide or urea, a large amount of amorphous carbon is also produced (20-25 wt\%). This can be minimized to $2 \mathrm{wt} \%$ by reducing the cyanamide or urea amount. The resulting TiN NCs have an average crystallite size of $3 \mathrm{~nm}$ and are aggregated to $50 \mathrm{~nm}$ agglomerates, embedded in amorphous carbon. Similarly, ZrN nanocrystals were synthesized by reacting $10-15 \mathrm{~nm} \mathrm{ZrO}_{2}$ nanocrystals with

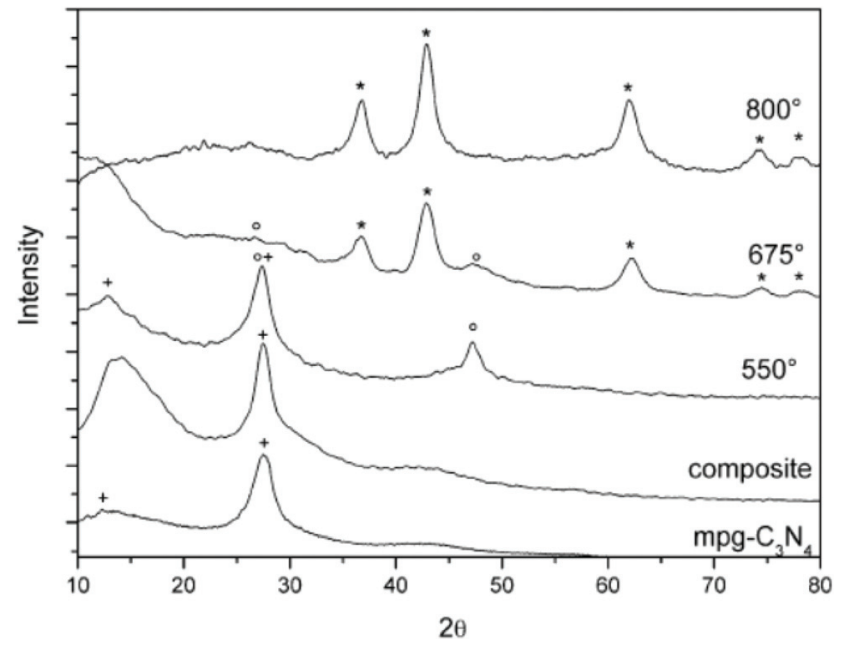

Fig. 6 Temperature-dependent powder XRD analysis of the $\mathrm{TiO}_{2}$ precursor/mpg- $\mathrm{C}_{3} \mathrm{~N}_{4}$ composites. (+) represents mpg- $\mathrm{C}_{3} \mathrm{~N}_{4}$; (o), $\mathrm{TiO}_{2}$; and $\left.{ }^{*}\right)$, TiN. Reprinted from ref. 66 with permission from John Wiley and Sons, Copyright 2007.

urea at $1100{ }^{\circ} \mathrm{C}$ under an ammonia flow. ${ }^{68}$ In 2009 , Antonietti and coworkers presented the "urea glass route" which is a combination of sol-gel chemistry and the above strategy of Buha et al. ${ }^{69}$ First, $\mathrm{TiCl}_{4}$ is dissolved in ethanol, forming titanium ethoxide and releasing $\mathrm{HCl}$ as side product. Then a varying amount of solid urea is added to the solution and stirred until complete dissolution and the solvent is allowed to evaporate. The metal center is mostly coordinated to urea via the carbonyl oxygen as shown by FTIR data. The gel was then heated under $\mathrm{N}_{2}$ flow at $800{ }^{\circ} \mathrm{C}$ for 3 hours at a very slow rate of $3{ }^{\circ} \mathrm{C} \mathrm{min}^{-1}$. A mechanism has been proposed based on thermal gravimetric analysis (TGA) and powder X-ray diffraction (XRD analysis. First, a glassy intermediate with nanoscale anatase and rutile titania is formed at $400{ }^{\circ} \mathrm{C}$. Second, at $600{ }^{\circ} \mathrm{C}$, loss of oxygen and metal reduction/nitridation is observed. Higher temperatures $\left(800^{\circ} \mathrm{C}\right)$ are required to obtain a complete recrystallization, see Fig. 7. A key parameter $R$ has

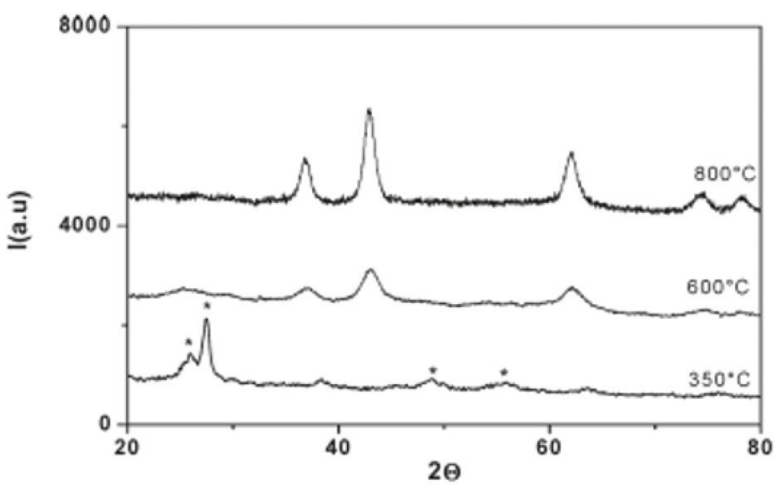

Fig. 7 XRD pattern of titanium-urea gels $(R=10)$ treated at different temperatures. The * symbol refers to crystalline $\mathrm{TiO}_{2}$. Reprinted with permission from ref. 69. Copyright 2009 American Chemical Society. 
been defined as the ratio of urea and titanium. For $R=3$, a mixture of TiN and $\mathrm{TiO}_{2}$ is obtained. Pure TiN is retrieved for $R=4$, while $\operatorname{Ti}(\mathrm{C}, \mathrm{N})$ was formed for $R=10$. The higher $R$, the higher the carbon contamination so the optimal ratio for TiN is four. The authors expanded the procedure to many other metal nitrides (VN, $\left.\mathrm{NbN}, \mathrm{GaN}, \mathrm{CrN}, \mathrm{Mo}_{2} \mathrm{~N}\right)$, but each metal has another optimal value for $R \cdot{ }^{69}$ Later, the method was also applied to produce $\mathrm{Sn}_{3} \mathrm{~N}_{4},{ }^{70} \mathrm{HfN},{ }^{47}$ and $\mathrm{ZrN},{ }^{46}$ as well as other nanocomposites such as graphene $\mathrm{g}-\mathrm{C}_{3} \mathrm{~N}_{4}$ doped with TiN. ${ }^{71,72}$ The nitride NCs obtained via this process are typically aggregated powders. Finally, other nitrogen sources were explored such as guanidine carbonate and barbituric acid. However, both features a particularly low solubility and it was not possible to achieve $R>1$. $^{69}$

In 2019, Karaballi and coworkers also synthesized TiN, ZrN and HfN NCs from their parent oxide NPs. ${ }^{40}$ Their strategy consists of a high temperature $\left(1000^{\circ} \mathrm{C}\right)$ solid-state metathesis reaction of magnesium nitride with commercial $\mathrm{TiO}_{2}(17 \mathrm{~nm})$, $\mathrm{ZrO}_{2}(19 \mathrm{~nm})$, and $\mathrm{HfO}_{2}(43 \mathrm{~nm})$.

$$
6 \mathrm{TiO}_{2}+4 \mathrm{Mg}_{3} \mathrm{~N}_{2} \underset{\text { Ar flow }}{\stackrel{1000^{\circ} \mathrm{C}, 1 \mathrm{~h}}{\longrightarrow}} 6 \mathrm{TiN}+12 \mathrm{MgO}+\mathrm{N}_{2}
$$

The final product is treated with $1 \mathrm{M} \mathrm{HCl}$ to remove $\mathrm{MgO}$ and unreacted $\mathrm{Mg}_{3} \mathrm{~N}_{2}$, and could be dispersed in water. ${ }^{40}$ All compounds have the expected cubic crystal structure and the nanocrystal size is 12, 15 and $11 \mathrm{~nm}$ for TiN, ZrN and HfN respectively. The NCs seem aggregated on transmission electron microscopy (TEM) but it is unclear whether this occurred during the sample preparation or already in solution. The reaction could be easily scaled to $1 \mathrm{~g}$ of metal nitride. Efforts to significantly increase the particle size by using larger oxide NCs were unsuccessful, indicating new nucleation events of the nitride, rather than a simply anion exchange reaction. The localized surface plasmon resonance of the NCs is blue-shifted and more narrow in the series: TiN, $\mathrm{ZrN}$ and HfN (Fig. 1). Finally, all particles were slightly oxidized at the surface and this effect was worse for $\mathrm{ZrN}$ and $\mathrm{HfN}$, compared to TiN. This scalable strategy of Karaballi et al. appears to produce high quality group 4 nitrides. While they are highly crystalline, their size dispersion could be improved. The method has already been adopted by other groups to produce, e.g., plasmonic HfN nanocrystals. $^{73}$

In 2017, Kan et al. explored molten salts (here: a eutectic mixture of $\mathrm{MgCl}_{2}$ and $\mathrm{NaCl}$ ) as a reaction medium for the synthesis of $\mathrm{TiN}$ from $\mathrm{TiO}_{2}$ and $\mathrm{Mg}$ powder under $\mathrm{N}_{2}$ atmosphere. The use of a higher $\mathrm{Mg}$ equivalent versus $\mathrm{TiO}_{2}$ (up to 4 equivalent), higher heating temperature (up to $1100{ }^{\circ} \mathrm{C}$ ), or longer reaction time (up to $7 \mathrm{~h}$ ) leads to phase pure TiN with a better crystallinity as judged by the well-defined diffraction peaks obtained by XRD. The authors obtained 5-30 nm aggregated TiN NPs by using 2.5 equivalent of $\mathrm{Mg}$ heated at $1100{ }^{\circ} \mathrm{C}$ for $3 \mathrm{~h}$. The authors described the mechanism as being a dissolution-precipitation type based on the increase of the surface area from the starting $\mathrm{TiO}_{2}\left(9.83 \mathrm{~m}^{2} \mathrm{~g}^{-1}\right)$ to the obtained TiN $\left(93.09 \mathrm{~m}^{2} \mathrm{~g}^{-1}\right) .^{74}$

\section{Group 5 metal nitrides}

Group 5 metal nitrides ( $\mathrm{VN}, \mathrm{NbN}$ and $\mathrm{TaN}$ ) have the same crystal structure as group 4 metal nitrides; a cubic crystal structure with a $F m \overline{3} m$ space group with a lattice constant of $4.13 \AA{ }^{75} 4.394 \AA{ }^{49}$ and $4.331 \AA$ (ref. 76) respectively. These group 5 nitrides exist as well in other oxidation states with less common crystal structures (orthorhombic, tetragonal and hexagonal), e.g., $\mathrm{Ta}_{3} \mathrm{~N}_{5}, \mathrm{Ta}_{4} \mathrm{~N}_{5}$ or $\mathrm{Ta}_{5} \mathrm{~N}_{6}$. Vanadium nitride has attracted interest as an active material for supercapacitors (SC) due to its high specific capacitance as well as high electrical conductivity. ${ }^{77}$ Niobium nitrides $\left(\mathrm{Nb}_{2} \mathrm{~N}, \mathrm{Nb}_{4} \mathrm{~N}_{3}, \mathrm{NbN}\right.$, etc. $)$ are mainly investigated as superconductors. Furthermore, nitrogen-rich niobium nitrides are good candidates for electrochemical capacitors. ${ }^{78,79}$

$\mathrm{VN}$ and $\mathrm{NbN}$ nanopowders were synthesized via the urea glass route (see above). ${ }^{69}$ Agglomerated VN NCs with a crystallite size of $6 \mathrm{~nm}$ have been synthesized by Choi et al. via a twostep method. First, ammonolysis of $\mathrm{VCl}_{4}$ forms amorphous $\mathrm{V}\left(\mathrm{NH}_{2}\right)_{3} \mathrm{Cl}$. Second, the amorphous precursor is crystallized at $400{ }^{\circ} \mathrm{C}$ in the presence of $\mathrm{NH}_{4} \mathrm{Cl}$ under an ammonia atmosphere. ${ }^{80}$ This method is one of the main chemical methods to form VN NCs, ${ }^{81}$ as well as NbN NCs. ${ }^{82}$

In 1972, $\mathrm{Ta}_{3} \mathrm{~N}_{5}$ powder and thin films were obtained at $1100 \mathrm{~K}$ starting from ammonia and $\mathrm{Ta}_{2} \mathrm{O}_{5}$ powder or Ta thin films respectively. ${ }^{83}$ This strategy was recently pursued to prepare $\mathrm{Ta}_{3} \mathrm{~N}_{5}$ nanotubes. ${ }^{84}$ In 1995, TaN films were made using the CVD method with tert-butylimidotris(diethylamido) tantalum as precursor at temperatures ranging from $450{ }^{\circ} \mathrm{C}$ to $650{ }^{\circ} \mathrm{C} .{ }^{85}$ Nanocrystalline TaN with a cubic phase has been synthesized via a solid combustion synthesis using $\mathrm{K}_{2} \mathrm{TaF}_{7}, \mathrm{NaN}_{3}$, and $\mathrm{NH}_{4} \mathrm{~F}$ precursors under high temperatures up to 850 to $950{ }^{\circ} \mathrm{C} .{ }^{86}$

In 2011, Ho et al. have reported three methods for the synthesis of colloidal $\mathrm{Ta}_{3} \mathrm{~N}_{5}$ NCs. ${ }^{87}$ In their first method $\mathrm{TaCl}_{5}$ is dispersed in octadecene (ODE). At $310{ }^{\circ} \mathrm{C}$, tris(trimethylsilyl) amine $\left((\mathrm{TMS})_{3} \mathrm{~N}\right.$, dissolved in trioctylphosphine) is injected and the particles are left to crystallize for $20 \mathrm{~min}$ at $300^{\circ} \mathrm{C}$.

$$
\mathrm{TaCl}_{5}+\mathrm{R}_{3} \mathrm{P}+(\mathrm{TMS})_{3} \mathrm{~N} \underset{\mathrm{ODE}}{\stackrel{300-310^{\circ} \mathrm{C}}{\longrightarrow}} \mathrm{Ta}_{3} \mathrm{~N}_{5}
$$

The resulting NCs (23 nm, see Fig. 8A) could not be redispersed in any solvent after precipitation due to a lack of strongly binding ligands. Smaller $(10 \mathrm{~nm})$ NCs were formed at a reaction temperature of $200{ }^{\circ} \mathrm{C}$. The authors report that the synthesis is sensitive to the purity of $\mathrm{TaCl}_{5}$; at least $99.99 \%$ purity is required, and even then the yield was very low (which was attributed to the low solubility of $\mathrm{TaCl}_{5}$ in ODE). In their second method, tantalum chloride was dissolved in a mixture of oleylamine (OLAm) and trioctylphosphine oxide (TOPO). $\mathrm{Li}_{3} \mathrm{~N}$ was added at $300{ }^{\circ} \mathrm{C}$.

$$
\mathrm{TaCl}_{5}+\mathrm{Li}_{3} \mathrm{~N} \underset{\text { TOPO, OLAm }}{\stackrel{300^{\circ} \mathrm{C}}{\longrightarrow}} \mathrm{Ta}_{3} \mathrm{~N}_{5}
$$

The resulting NCs (2-8 $\mathrm{nm}$ after $20 \mathrm{~min}$ reaction, see Fig. $8 \mathrm{~B}$ ) could be redispersed in hexane after precipitation with 

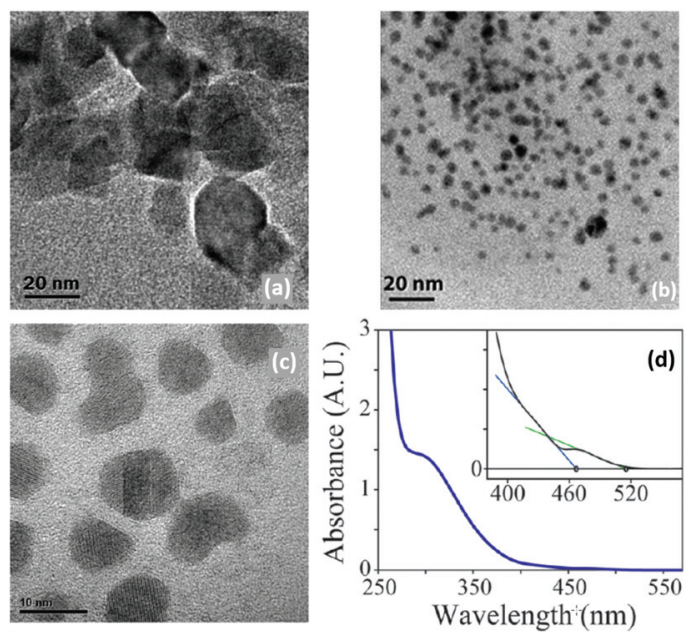

Fig. 8 TEM images of $\mathrm{Ta}_{3} \mathrm{~N}_{5}$ obtained by Ho et al. ${ }^{87}$ (a) NPs obtained with $\mathrm{TaCl}_{5}$ and $(\mathrm{TMS})_{3} \mathrm{~N}$ (scale $20 \mathrm{~nm}$ ), (b) with $\mathrm{Ta}\left(\mathrm{NMe}_{2}\right)_{5}$ and $(\mathrm{TMS})_{3} \mathrm{~N}$ (scale $20 \mathrm{~nm}$ ) (c) with $\mathrm{TaCl}_{5}$ and $\mathrm{Li}_{3} \mathrm{~N}$ (scale $10 \mathrm{~nm}$ ). (d) Absorption spectrum of the obtained $10 \mathrm{~nm} \mathrm{Ta} \mathrm{N}_{5}$. The inset showing the two limiting regimes. Adapted with permission from ref. 87. Copyright 2010 American Chemical Society.

methanol. When the reaction is left to proceed for 1 hour, $10 \mathrm{~nm}$ NCs are obtained. Their absorption spectrum has two absorption onsets (467 $\mathrm{nm}$ and $515 \mathrm{~nm}$ ) which is explained by the absorption of $\mathrm{Ta}_{3} \mathrm{~N}_{5}(515 \mathrm{~nm})$ and that of a higher bandgap material, likely an oxidized shell. XPS data indeed confirm the presence of oxidic tantalum. To counter the low yields in the previous methods, the authors devised a third method. Pentakis(dimethylamido)tantalum and (TMS) ${ }_{3} \mathrm{~N}$ were dissolved in ODE and injected in pure ODE at $300^{\circ} \mathrm{C}$ (Fig. $8 \mathrm{C}$ ). However, the formed particles were amorphous and highly sensitive to air. ${ }^{87}$ For all three methods, the crystallinity of the resulting particles was solely assessed by TEM and an ensemble measurement (e.g., XRD) is missing.

$$
\mathrm{Ta}\left(\mathrm{NMe}_{2}\right)_{5}+(\mathrm{TMS})_{3} \mathrm{~N} \underset{\mathrm{ODE}}{\stackrel{300^{\circ} \mathrm{C}}{\longrightarrow}} \mathrm{TaN}_{x}
$$

In 2013, a sol-gel pathway was demonstrated with $\mathrm{Ta}\left(\mathrm{NMe}_{2}\right)_{5}$ and $n$-propylamine. ${ }^{88}$ Transamination occurs readily but the condensation appears to be slower than for titanium (see section on titanium nitride for details on transamination and condensation). Upon solvent evaporation a gel was formed. Solvent removal by vacuum resulted in a xerogel that converted in an ammonia atmosphere at $800{ }^{\circ} \mathrm{C}$ into $\mathrm{Ta}_{3} \mathrm{~N}_{5}$ powder with a crystal size of $20 \mathrm{~nm}$. Thin films were obtained by coating the a silica slides with the sol. Firing at $600{ }^{\circ} \mathrm{C}$ leads to TaN while heating to $800{ }^{\circ} \mathrm{C}$ yields $\mathrm{Ta}_{3} \mathrm{~N}_{5}{ }^{88}$

It is thus clear from the above that nanocrystals of the group 5 nitrides have not been convincingly obtained in colloidal form. While this is the first challenge for the future, the second challenge is to control the oxidation state and the polymorphism of these materials.

\section{Nickel nitride}

Nickel nitride $\mathrm{Ni}_{3} \mathrm{~N}$ has a hexagonal epsilon- $\mathrm{Fe}_{3} \mathrm{~N}$-type structure with a $P 6(3) 22$ space group, see Fig. 9. The two lattice constants are $4.622 \AA$ and $4.305 \AA^{89}$ Nickel nitride is interesting for various applications such as lithium-ion batteries, ${ }^{90}$ magnetic NPs, ${ }^{91,92}$ catalysis and electrocatalysis, ${ }^{93,94}$ including hydrogenation, hydrogen, and oxygen evolution reactions (OER). ${ }^{95,96}$ The early chemical synthetic methods to obtain $\mathrm{Ni}_{3} \mathrm{~N}$ were based on the decomposition of nickel complexes at high temperatures and in presence of ammonia or hydrazine. ${ }^{90,92}$

Recently a one-step synthesis of colloidally stable $\mathrm{Ni}_{3} \mathrm{~N}$ NCs has been reported by Shanker et al. ${ }^{97}$ Nickel acetate is used as precursor and OLAm is chosen as ligand. Different nanocrystal sizes are obtained ( 5 to $80 \mathrm{~nm}$ ) by varying the time and temperature in a narrow window, see Fig. 10. The NCs are reasonably monodisperse and colloidally stable. The authors detect ammonia during the reaction and thus infer that ammonia is the nitrogen source. However, it is unclear how ammonia is being generated since the most logical reaction would be the formation of oleylacetamide and NiO. Furthermore, the synthesis requires a specific reagent purity and supplier.

$$
\mathrm{Ni}\left(\mathrm{CH}_{3} \mathrm{CO}_{2}\right)_{2}+2 \mathrm{RNH}_{2} \underset{\mathrm{ODE}}{\stackrel{210-230^{\circ} \mathrm{C}, 5-10 \mathrm{~min}}{\longrightarrow}} \mathrm{Ni}_{3} \mathrm{~N}
$$
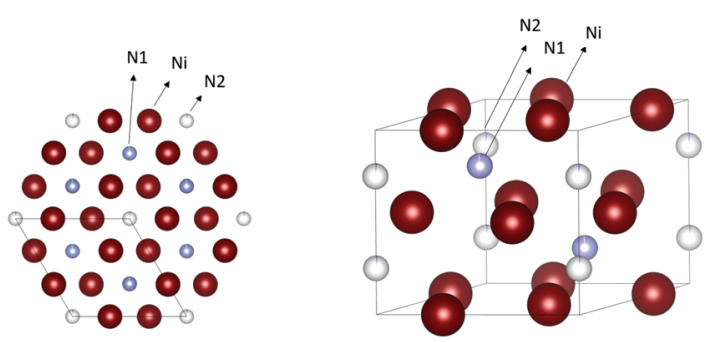

Fig. 9 Crystal structure of $\mathrm{Ni}_{3} \mathrm{~N}$. The nickel atoms are represented in dark red and the nitrogen atoms in cyan and white. Structures plotted using VESTA. ${ }^{48}$ Cif file obtained from ref. 89.
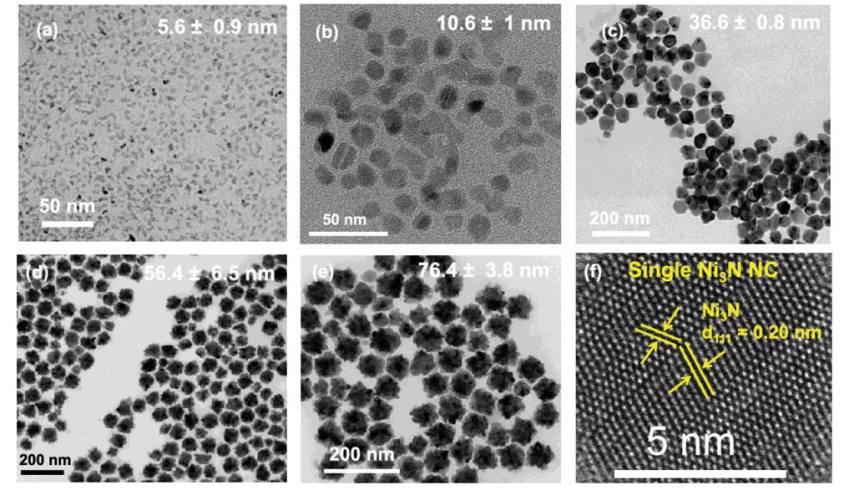

Fig. 10 TEM images of the different $\mathrm{Ni}_{3} \mathrm{~N} \mathrm{NCs}$ obtained. (a) $5.6 \pm 0.9 \mathrm{~nm}$, (b) $10.6 \pm 1.0 \mathrm{~nm}$, (c) $36.6 \pm 0.8 \mathrm{~nm}$, (d) $56.4 \pm 6.5 \mathrm{~nm}$, and (e) $76.4 \pm$ $3.8 \mathrm{~nm}$. (f) High resolution transmission electron microscopy (HRTEM) imageof a $\mathrm{Ni}_{3} \mathrm{~N}$ nanocrystal with a size of $56.4 \pm 6.5 \mathrm{~nm}$. Reprinted with permission from ref. 97. Copyright 2021 American Chemical Society. 


\section{Copper nitride}

Copper nitride, $\mathrm{Cu}_{3} \mathrm{~N}$, has an anti- $\mathrm{ReO}_{3}$ crystal structure with a Pm3m space group, and a lattice constant of $3.817 \AA$, see Fig. 11. ${ }^{98,99}$ Copper nitride is a semiconductor with a reported band-gap of $1.7 \mathrm{eV}$ which could be potentially interesting for solar cells. ${ }^{100}$ Thin films of copper nitride have been used in optical storage devices, ${ }^{101}$ and resistive random access memory chips. ${ }^{102} \mathrm{Cu}_{3} \mathrm{~N}$ NCs were applied as catalyst in the reduction of $\mathrm{CO}_{2}$ to ethylene, ${ }^{103}$ alkaline water electrolysis, ${ }^{104}$ and the oxygen reduction reaction (ORR). ${ }^{105} \mathrm{Cu}_{3} \mathrm{~N}$ can be doped with other metals such as $\mathrm{Pd}$ to form $\mathrm{Cu}_{3} \mathrm{Pd}_{x} \mathrm{~N}$ with $0.02<x<1$ which shows metallic behaviour. ${ }^{106-108}$ The crystal structure of the latter is similar to the $\mathrm{Cu}_{3} \mathrm{~N}$ structure, with a palladium atom in the center of the unit cell (with a larger lattice constant of $3.854 \AA$ ), see Fig. 11. $\mathrm{Cu}_{3} \mathrm{~N}$ forms at relatively low temperature but decomposes at higher temperature to metallic copper. Under inert atmosphere, copper nitride films decompose at $475{ }^{\circ} \mathrm{C},{ }^{101}$ and particles decompose at $300{ }^{\circ} \mathrm{C} .{ }^{109}$ When heated in air, $\mathrm{Cu}_{3} \mathrm{~N}$ decomposes to $\mathrm{CuO} .{ }^{109}$ We calculated an exciton Bohr radius of $3.12 \mathrm{~nm}$ for copper nitride based on the effective masses of electrons and holes, as reported by Birkett et al. ${ }^{110}$

In 1939 , Juza et al. synthesized $\mathrm{Cu}_{3} \mathrm{~N}$ powders by reacting $\mathrm{CuF}_{2}$ with ammonia gas (aminolyis reaction). ${ }^{113}$ Phase pure copper nitride was obtained at reaction temperatures between $250{ }^{\circ} \mathrm{C}$ and $325^{\circ} \mathrm{C}$ (6 hours reaction time). ${ }^{114}$ At higher temperatures, $\mathrm{Cu}(0)$ is formed. Alternatively, Zachweija and Jacobs synthesized $\mathrm{Cu}_{3} \mathrm{~N}$ by thermal decomposition of $\left[\mathrm{Cu}\left(\mathrm{NH}_{3}\right)_{x}\right]$ $\left(\mathrm{NO}_{3}\right){ }^{111}$ In 2005 , Choi et al. combined copper(II) chloride and sodium azide in superheated toluene or THF. ${ }^{109}$ The intermediate copper azide decomposes to $\mathrm{Cu}_{3} \mathrm{~N}$ powder at $185{ }^{\circ} \mathrm{C}$.

$$
\begin{gathered}
\mathrm{CuCl}_{2}+2 \mathrm{NaN}_{3} \frac{<120^{\circ} \mathrm{C}}{\text { THF or toluene }} \mathrm{Cu}\left(\mathrm{N}_{3}\right)_{2}+2 \mathrm{NaCl} \\
6 \mathrm{Cu}\left(\mathrm{N}_{3}\right)_{2} \underset{\text { THF or toluene }}{\stackrel{185^{\circ} \mathrm{C}}{\longrightarrow}} 2 \mathrm{Cu}_{3} \mathrm{~N}+17 \mathrm{~N}_{2}
\end{gathered}
$$

The reaction temperature is remarkably lower than previously reported for the similar synthesis of other metal nitrides such as TiN and GaN. Unfortunately, the reaction time is very long (about three days) and metal azides are thermally
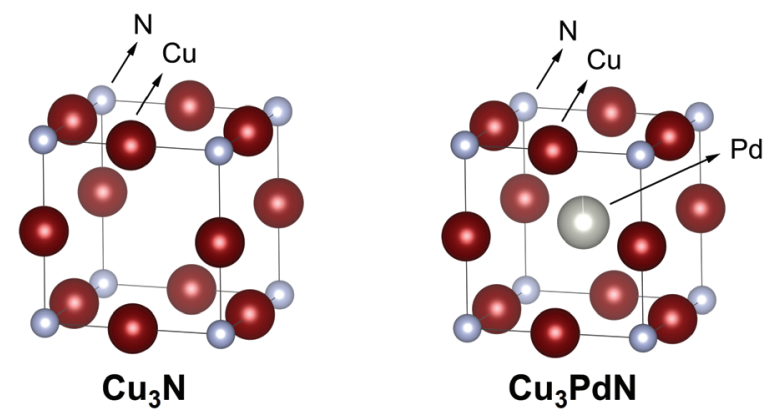

Fig. 11 Crystal structure of $\mathrm{Cu}_{3} \mathrm{~N}$ and the doped $\mathrm{Cu}_{3} \mathrm{PdN}$. The copper is represented in dark red, the palladium in grey and the nitrogen atom in cyan. Structures plotted using VESTA. ${ }^{48}$ Cif file obtained from ref. 111 and 112. unstable and shock sensitive, which limits the reaction to small scales. Finally, the obtained $\mathrm{Cu}_{3} \mathrm{~N}$ is not phase-pure and some $\mathrm{NaCl}$ impurities remain present in the sample.

\section{1. $\mathrm{Cu}_{3} \mathrm{~N}$ nanocrystal synthesis from copper nitrate and primary amine}

In 2011, Wang et al. obtained colloidally stable $\mathrm{Cu}_{3} \mathrm{~N}$ NCs by reacting $\mathrm{Cu}\left(\mathrm{NO}_{3}\right)_{2} \cdot 3 \mathrm{H}_{2} \mathrm{O}$ in octadecylamine (ODA) at 220-280 ${ }^{\circ} \mathrm{C}^{115}$ Octadecylamine acts here both as solvent and as ligand.

$$
\mathrm{Cu}\left(\mathrm{NO}_{3}\right)_{2}+32 \mathrm{RNH}_{2} \underset{10-60 \mathrm{~min}}{\stackrel{220-280^{\circ} \mathrm{C}}{\longrightarrow}} \mathrm{Cu}_{3} \mathrm{~N}
$$

The authors hypothesize that $\mathrm{NO}_{2}$ and $\mathrm{O}_{2}$ are formed as side products but did not provide experimental evidence. This hypothesis was based on the solid state decomposition reaction of $\mathrm{Cu}\left(\mathrm{NO}_{3}\right)_{2} \cdot 3 \mathrm{H}_{2} \mathrm{O}$ into $\mathrm{CuO}, \mathrm{NO}_{2}$ and $\mathrm{O}_{2}$ at around $180{ }^{\circ} \mathrm{C} .{ }^{116}$ The size of the NCs is tuned by using different reaction temperatures $\left(220-280^{\circ} \mathrm{C}\right.$ ) and reaction times (5-20 min). The conditions and their outcomes are also summarized in Table 2. Pure $\mathrm{Cu}_{3} \mathrm{~N}$ NCs are only obtained with 32 equivalents of ODA. $\mathrm{Cu}_{2} \mathrm{O}$ is obtained with 8 equivalents, while 80 equivalents lead to $\mathrm{Cu}(0)$ NCs. Forty and thirteen equivalents lead to a mixture of $\mathrm{Cu} / \mathrm{Cu}_{3} \mathrm{~N}$ or $\mathrm{Cu}_{3} \mathrm{~N} / \mathrm{Cu}_{2} \mathrm{O}$ mixture respectively. Please note that the copper concentration also changes in these experiments since ODA is the solvent. Wang et al. argue that nitrate $\left(\mathrm{NO}_{3}{ }^{-}\right)$is the nitrogen source for the nitride $\left(\mathrm{N}^{3-}\right)$, even though this would involve the transfer of eight electrons to $\mathrm{N}(\mathrm{v})$ in nitrate. They based their argument on the observation that copper nitrate is the only precursor that delivers copper nitride. Copper chloride does not yield any products while copper acetate yields a $\mathrm{Cu}(0) / \mathrm{Cu}_{2} \mathrm{O}$ mixture and copper sulfate delivers copper sulfide NCs. However, no other hypotheses were tested or disproved, thereby leaving the option open that the nitride is provided by ODA, as is the case for certain syntheses of InN NCs (see below).

Also in 2011, Wu and co-workers described the formation of $\mathrm{Cu}_{3} \mathrm{~N}$ from $\mathrm{Cu}\left(\mathrm{NO}_{3}\right)_{2} \cdot 3 \mathrm{H}_{2} \mathrm{O}$ in the presence of both a primary amine (surfactant) and octadecene (ODE) (solvent), see eqn (11). ${ }^{117}$ By changing the primary amine (ODA, hexadecylamine or OLAm), the size of the final $\mathrm{Cu}_{3} \mathrm{~N}$ varies from $26 \pm 5.6 \mathrm{~nm}$ to $18 \pm 2.3 \mathrm{~nm}$ and $10 \pm 2.7 \mathrm{~nm}$ respectively (Fig. 12). All NCs have a cubic morphology and are phase-pure copper nitride.

$$
\mathrm{Cu}\left(\mathrm{NO}_{3}\right)_{2}+66 \mathrm{RNH}_{2} \underset{250^{\circ} \mathrm{C}, 30 \mathrm{~min}}{\stackrel{150^{\circ} \mathrm{C}, 3 \mathrm{~h}}{\longrightarrow}} \mathrm{Cu}_{3} \mathrm{~N}
$$

In a first stage, the reaction is heated to $150{ }^{\circ} \mathrm{C}$ with a concomitant color change from dark blue to green and then yellow, indicating the reduction of $\mathrm{Cu}(\mathrm{II})$ to $\mathrm{Cu}(\mathrm{I}){ }^{115}$ Subsequently, the solution is heated to $250{ }^{\circ} \mathrm{C}$ for $30 \mathrm{~min}$ and the solution turns brown, consistent with the formation of copper nitride. According to Wu et al. ODE is necessary as solvent to obtain well-defined nanocubes since irregular and polydisperse $\mathrm{Cu}_{3} \mathrm{~N}$ NCs have been obtained using only OLAm. Most likely, other solvents would be more suitable since ODE polymerizes during nanocrystal synthesis. ${ }^{27}$ Nonetheless, this 
Table 2 Synthetic conditions for colloidal copper nitride NCs

\begin{tabular}{|c|c|c|c|c|c|c|c|c|c|}
\hline Precursor $^{a}$ & $\begin{array}{l}{[\mathrm{Cu}]} \\
(\mathrm{mM})\end{array}$ & $\begin{array}{l}\text { Solvent }{ }^{b} / \\
\text { ligand }^{c}\end{array}$ & $\begin{array}{l}\text { Ligand/ } \\
\text { Cu ratio }\end{array}$ & $\begin{array}{l}\text { Temperature } \\
\left({ }^{\circ} \mathrm{C}\right)\end{array}$ & $\begin{array}{l}\text { Time } \\
\text { (min) }\end{array}$ & Morphology & Phase & $\begin{array}{l}\text { Size } \\
(\mathrm{nm})\end{array}$ & Ref. \\
\hline $\mathrm{Cu}\left(\mathrm{NO}_{3}\right)_{2} \cdot 3 \mathrm{H}_{2} \mathrm{O}$ & 101 & ODA & 32 & 240 & 10 & Cubic & $\mathrm{Cu}_{3} \mathrm{~N}$ & 15 & 115 \\
\hline $\mathrm{Cu}\left(\mathrm{NO}_{3}\right)_{2} \cdot 3 \mathrm{H}_{2} \mathrm{O}$ & 101 & ODA & 32 & 280 & 5 & Spherical & $\mathrm{Cu}_{3} \mathrm{~N}$ & 10 & 115 \\
\hline $\mathrm{Cu}\left(\mathrm{NO}_{3}\right)_{2} \cdot 3 \mathrm{H}_{2} \mathrm{O}$ & 101 & ODA & 32 & $260+240$ & $5+5$ & Spherical & $\mathrm{Cu}_{3} \mathrm{~N}$ & 15 & 115 \\
\hline $\mathrm{Cu}\left(\mathrm{NO}_{3}\right)_{2} \cdot 3 \mathrm{H}_{2} \mathrm{O}$ & 101 & ODA & 32 & $220+240$ & $5+5$ & Spherical & $\mathrm{Cu}_{3} \mathrm{~N}$ & 15 & 115 \\
\hline $\mathrm{Cu}\left(\mathrm{NO}_{3}\right)_{2} \cdot 3 \mathrm{H}_{2} \mathrm{O}$ & 101 & ODA & 32 & 220 & 20 & Irregular & $\mathrm{Cu}_{3} \mathrm{~N}$ & 50 & 115 \\
\hline $\mathrm{Cu}\left(\mathrm{NO}_{3}\right)_{2} \cdot 3 \mathrm{H}_{2} \mathrm{O}$ & & ODA & 40 & 240 & 10 & & $\mathrm{Cu}+\mathrm{Cu}_{3} \mathrm{~N}$ & & 115 \\
\hline $\mathrm{Cu}\left(\mathrm{NO}_{3}\right)_{2} \cdot 3 \mathrm{H}_{2} \mathrm{O}$ & & ODA & 13 & 240 & 10 & & $\mathrm{CuO}+\mathrm{Cu}_{3} \mathrm{~N}$ & & 115 \\
\hline $\mathrm{Cu}\left(\mathrm{NO}_{3}\right)_{2} \cdot 3 \mathrm{H}_{2} \mathrm{O}$ & 24 & ODE/ODA & 67 & 250 & 30 & Cubic & $\mathrm{Cu}_{3} \mathrm{~N}$ & 26 & 117 \\
\hline $\mathrm{Cu}\left(\mathrm{NO}_{3}\right)_{2} \cdot 3 \mathrm{H}_{2} \mathrm{O}$ & 24 & ODE/HDA & 69 & 250 & 30 & Cubic & $\mathrm{Cu}_{3} \mathrm{~N}$ & 19 & 117 \\
\hline $\mathrm{Cu}\left(\mathrm{NO}_{3}\right)_{2} \cdot 3 \mathrm{H}_{2} \mathrm{O}$ & 24 & ODE/OLAm & 63 & 250 & 30 & Cubic & $\mathrm{Cu}_{3} \mathrm{~N}$ & 11 & 117 \\
\hline $\mathrm{Cu}\left(\mathrm{NO}_{3}\right)_{2} \cdot 3 \mathrm{H}_{2} \mathrm{O}$ & 24 & OLAm & & 250 & 30 & Irregular & $\mathrm{Cu}_{3} \mathrm{~N}$ & & 117 \\
\hline $\mathrm{Cu}\left(\mathrm{NO}_{3}\right)_{2} \cdot 3 \mathrm{H}_{2} \mathrm{O}$ & 25 & ODE/OLAm & 31 & 240 & 15 & Cubic & $\mathrm{Cu}_{3} \mathrm{~N}$ & & 118 \\
\hline $\mathrm{Cu}\left(\mathrm{NO}_{3}\right)_{2} \cdot 3 \mathrm{H}_{2} \mathrm{O}+\mathrm{Pd}(\text { acac })_{2}$ & 25 & ODE/OLAm & 31 & 240 & 15 & Cubic & $\mathrm{Cu}_{3} \mathrm{PdN}$ & 16 & 118 \\
\hline $\mathrm{Cu}\left(\mathrm{NO}_{3}\right)_{2} \cdot 3 \mathrm{H}_{2} \mathrm{O}+\mathrm{Pd}(\mathrm{acac})_{2}$ & 25 & ODE/OLAm & 31 & 190 & 30 & Cubic & $\mathrm{Cu}_{3} \mathrm{PdN}$ & & 119 \\
\hline $\mathrm{Cu}\left(\mathrm{NO}_{3}\right)_{2} \cdot 3 \mathrm{H}_{2} \mathrm{O}$ & 25 & ODE/OLAm & 31 & 210 & 30 & Cubic & $\mathrm{Cu}_{3} \mathrm{~N}$ & & 119 \\
\hline $\mathrm{Cu}\left(\mathrm{NO}_{3}\right)_{2} \cdot 3 \mathrm{H}_{2} \mathrm{O}$ & 75 & ODA/OLAm & 45 & 240 & 20 & Cubic & $\mathrm{Cu}_{3} \mathrm{~N}$ & 25 & 105 \\
\hline $\mathrm{Cu}\left(\mathrm{NO}_{3}\right)_{2} \cdot 3 \mathrm{H}_{2} \mathrm{O}$ & 88 & ODA/OLAm & 41 & 240 & 30 & Cubic & $\mathrm{Cu}_{3} \mathrm{~N}$ & 25 & 103 \\
\hline $\mathrm{Cu}\left(\mathrm{NO}_{3}\right)_{2} \cdot 3 \mathrm{H}_{2} \mathrm{O}$ & 88 & ODA/OLAm & 41 & 250 & 30 & Cubic & $\mathrm{Cu}_{3} \mathrm{~N}$ & 20 & 103 \\
\hline $\mathrm{Cu}\left(\mathrm{NO}_{3}\right)_{2} \cdot 3 \mathrm{H}_{2} \mathrm{O}$ & 88 & ODA/OLAm & 41 & 260 & 30 & Cubic & $\mathrm{Cu}_{3} \mathrm{~N}$ & 10 & 103 \\
\hline $\mathrm{Cu}\left(\mathrm{NO}_{3}\right)_{2} \cdot 3 \mathrm{H}_{2} \mathrm{O}$ & 88 & ODA/OLAm & 41 & 230 & 30 & Spherical & $\mathrm{Cu}_{3} \mathrm{~N}$ & 20 & 103 \\
\hline $\mathrm{Cu}\left(\mathrm{NO}_{3}\right)_{2} \cdot 5 \mathrm{H}_{2} \mathrm{O}+\mathrm{HMT}$ & 50 & Hexanol & - & 200 & 60 & Spherical & $\mathrm{Cu}_{3} \mathrm{~N}$ & 80 & 122 \\
\hline $\mathrm{Cu}(\text { acetate })_{2} \cdot \mathrm{H}_{2} \mathrm{O}+\mathrm{NH}_{3}$ & 10 & Nonanol & - & 190 & 60 & Spherical & $\mathrm{Cu}_{3} \mathrm{~N}$ & 200 & 123 \\
\hline PPC & 50 & ODA & 74 & 260 & 5 & Spherical & $\mathrm{Cu}_{3} \mathrm{~N}$ & 3 & 124 \\
\hline $\mathrm{Cu}\left(\mathrm{NO}_{3}\right)_{2} \cdot 3 \mathrm{H}_{2} \mathrm{O}$ & 50 & ODA & 74 & 260 & 5 & Cubic & $\mathrm{Cu}_{3} \mathrm{~N}$ & 19 & 124 \\
\hline $\mathrm{Cu}(\mathrm{OMe})_{2}$ & 92 & $\mathrm{BnNH}_{2}$ & 117 & 140 & 15 & Spherical & $\mathrm{Cu}_{3} \mathrm{~N}$ & 2 & 125 \\
\hline $\mathrm{CuI}+\mathrm{KNH}_{2}+\mathrm{NH}_{3}$ & 21 & Pyridine & - & $-35+130$ & $10+30$ & Spherical & $\mathrm{Cu}_{3} \mathrm{~N}$ & 4 & 126 \\
\hline
\end{tabular}

${ }^{a} \mathrm{HMT}=$ hexamethylenetetraamine, $\mathrm{PPC}=$ pyrrole-2-carbaldpropyliminato $\mathrm{Cu}(\mathrm{II}) .{ }^{b} \mathrm{ODE}=1$-ODE. ${ }^{c} \mathrm{ODA}=$ octadecylamine, $\mathrm{OLAm}=$ oleylamine, HDA = hexadecylamine.
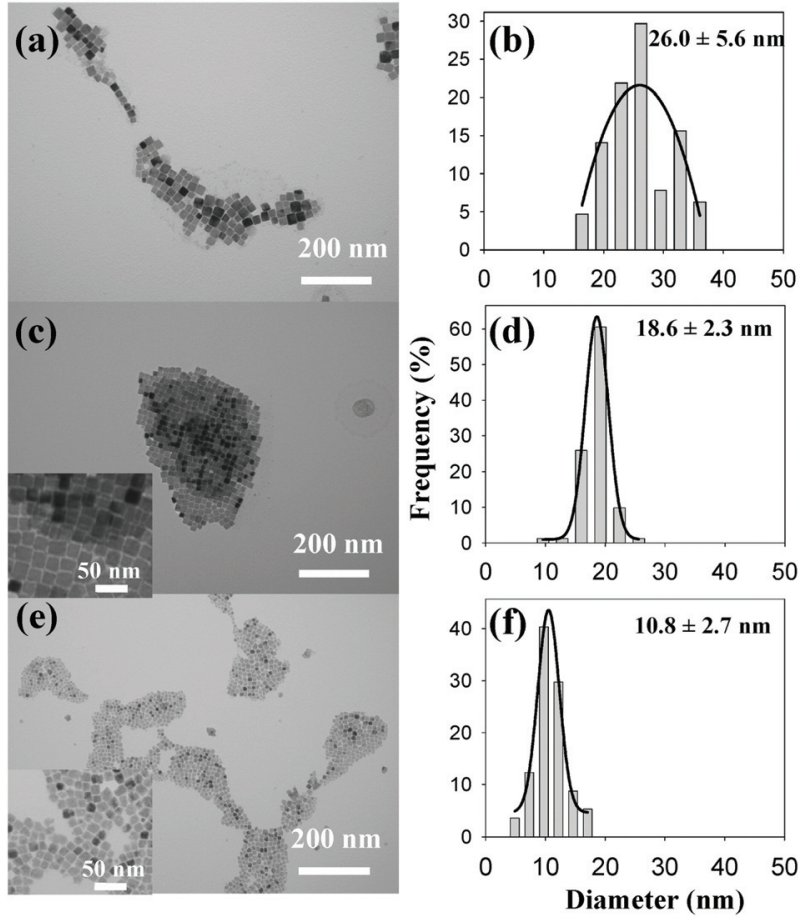

Fig. 12 TEM images and the corresponding size histograms of $\mathrm{Cu}_{3} \mathrm{~N} N C s$ synthesized from copper nitrate and various primary amines in ODE solvent, according to ref. 117. (a, b) Octadecylamine (c, d) hexadecylamine, and $(e, f)$ oleylamine. Reprinted with permission from ref. 117. Copyright 2011 American Chemical Society. Note that the authors labelled the axis diameter. Given the cubic morphology of the nanocrystals, this is confusing and the cube edge length is a more appropriate measure for the size. method was adopted by other groups and Vaughn II et al. used it to produce $\mathrm{Cu}_{3} \mathrm{~N}$ and $\mathrm{Cu}_{3} \mathrm{PdN}$, albeit with half the number of amine equivalents, see also Table $2 .{ }^{118}$ The reaction mixture is degassed for $10 \mathrm{~min}$ at $120{ }^{\circ} \mathrm{C}$ and then heated to $240{ }^{\circ} \mathrm{C}$ under argon for $15 \mathrm{~min}$. To produce $\mathrm{Cu}_{3} \mathrm{Pd}_{x} \mathrm{~N}, \mathrm{Pd}(\mathrm{acac})_{2}$ is also added at the start. The average diameter of the quasicubic $\mathrm{Cu}_{3} \mathrm{PdN}$ NCs is $16 \pm 2 \mathrm{~nm}$. $\mathrm{Cu}_{3} \mathrm{~N}$ and $\mathrm{Cu}_{3} \mathrm{PdN}$ can also be grown on $\mathrm{Pt}$ and $\mathrm{Au}$ nanoparticle seeds to form nanoscale heterostructures at $190{ }^{\circ} \mathrm{C}$ see Fig. $13 .{ }^{119}$

In 2019, Braman et al. synthesized Au decorated $\mathrm{Cu}_{3} \mathrm{~N}$ NCs. First, $\mathrm{Cu}_{3} \mathrm{~N}$ NCs $(10 \pm 5 \mathrm{~nm})$ were obtained via a similar approach to the one of Vaughn et al. but with a higher amine equivalent and a lower heating temperature $\left(210{ }^{\circ} \mathrm{C}\right)$. Subsequently, Au NPs were grown on top of the $\mathrm{Cu}_{3} \mathrm{~N}$ cubes. The resulting heterostructure demonstrated a better catalytic activity than pure $\mathrm{Cu}_{3} \mathrm{~N} .{ }^{120}$

In 2014, Xi et al. performed the reaction in a mixture of ODA and OLAm. ${ }^{105}$ First the mixture is heated to $110{ }^{\circ} \mathrm{C}$ and than quickly heated to $240{ }^{\circ} \mathrm{C}$ for $10 \mathrm{~min}$. They obtained uniform nanocubes of $\mathrm{Cu}_{3} \mathrm{~N}$ of around $20 \mathrm{~nm}$. The growth mechanism was investigated by analyzing reaction aliquots at 2, 5 and $10 \mathrm{~min}$. From TEM measurements (Fig. 14), Xi et al. conclude that first small NPs are formed, which subsequently ripen into bigger nanocubes. This growth mechanism was later confirmed under slightly different conditions. ${ }^{121}$ In addition, long reaction times (at $260^{\circ} \mathrm{C}$ ) lead to the decomposition of the formed $\mathrm{Cu}_{3} \mathrm{~N}$ to $\mathrm{Cu}(0)$ particles. Xi et al. also studied the magnetic properties of the $\mathrm{Cu}_{3} \mathrm{~N}$ NCs and observed 


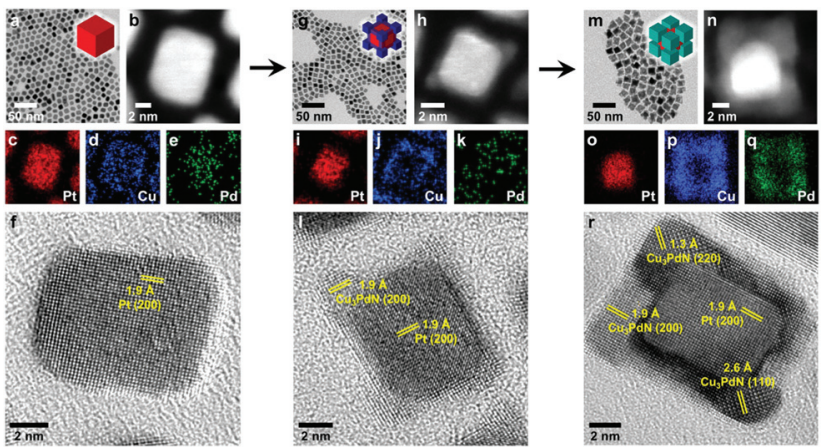

Fig. 13 Time-dependent growth studies of $\mathrm{Cu}_{3} \mathrm{PdN}$ on Pt nanocubes at $170{ }^{\circ} \mathrm{C}$ for $(a-f) 5 \mathrm{~min},(\mathrm{~g}-\mathrm{l}) 10 \mathrm{~min}$, and $(\mathrm{m}-\mathrm{r}) 15 \mathrm{~min}$. The data for each time point include $(a, g$, and $m)$ TEM images, $(b, h$, and $n)$ HAADF-STEM images, ( $c-e, i-k$, and $\mathrm{o}-\mathrm{q}$ ) energy dispersive $\mathrm{X}$-ray spectroscopy (STEM-EDS) element maps for Pt (red), Cu (blue), and Pd (green), and ( $f$, $\mathrm{l}$, and $r$ ) HRTEM images of individual particles. Reprinted with permission from ref. 119, Copyright 2019 American Chemical Society.

(A)
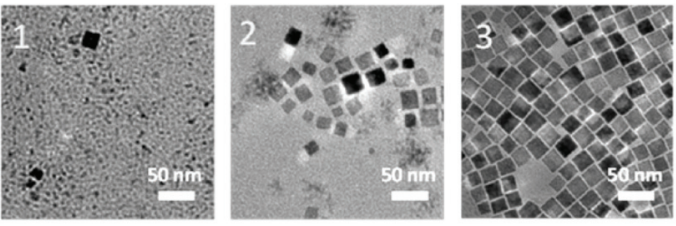

(B)

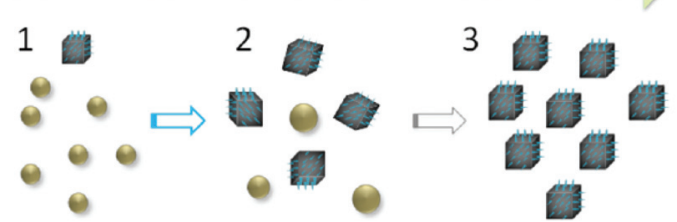

Fig. 14 (A) TEM of the $\mathrm{Cu}_{3} \mathrm{~N}$ NCs synthesized according to ref. 105, after 2, 5 and $10 \mathrm{~min}$. (B) The proposed growth procedure of $\mathrm{Cu}_{3} \mathrm{~N}$ nanocubes. Reproduced from ref. 105 with permission from the Royal Society of Chemistry.

paramagnetic and ferromagnetic contributions. Such properties are not expected for $\mathrm{d}^{0}$ materials and are assumed to originate from surface defects. ${ }^{105}$

In 2019, Yin et al. used the same strategy of Xi et al. By tuning the heating temperature, the size and morphology of the final $\mathrm{Cu}_{3} \mathrm{~N}$ is changed, see Table $2 .{ }^{103}$ Above $240{ }^{\circ} \mathrm{C}$ cubic NCs are formed while below $240{ }^{\circ} \mathrm{C}$ spherical NCs are formed. The size of the final $\mathrm{Cu}_{3} \mathrm{~N}$ decreases from $25 \mathrm{~nm}$ to $10 \mathrm{~nm}$ by increasing the reaction temperature from $240{ }^{\circ} \mathrm{C}$ to $260{ }^{\circ} \mathrm{C}$. The $\mathrm{Cu}_{3} \mathrm{~N}$ NCs are stable even after 2 weeks of air exposure and no degradation is observed in the crystal structure and morphology.

\section{2. $\mathrm{Cu}_{3} \mathrm{~N}$ nanocrystal synthesis from $\mathrm{Cu}(\mathrm{OMe})_{2}$ and benzylamine}

Deshmukh et al. reacted $\mathrm{Cu}(\mathrm{OMe})_{2}$ in benzylamine $\left(\mathrm{BnNH}_{2}\right)$ and obtained very small, spherical $\mathrm{Cu}_{3} \mathrm{~N}$ NCs $(2.2 \pm 0.5 \mathrm{~nm}) .{ }^{125,127}$

$$
\mathrm{Cu}(\mathrm{OMe})_{2}+117 \mathrm{BnNH}_{2} \underset{15 \mathrm{~min}}{\stackrel{140^{\circ} \mathrm{C}}{\longrightarrow}} \mathrm{Cu}_{3} \mathrm{~N}
$$

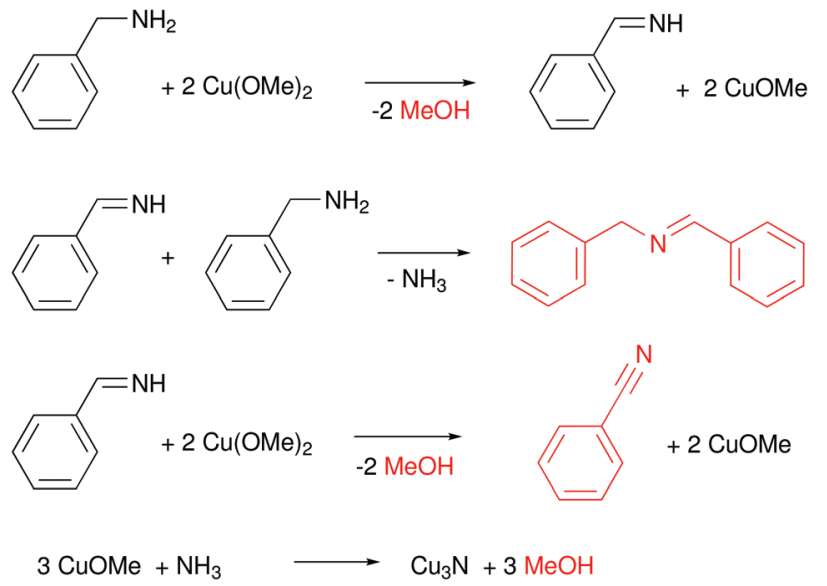

Fig. 15 Proposed reaction mechanism of $\mathrm{Cu}(\mathrm{OMe})_{2}$ with $\mathrm{BnNH}_{2}$ that leads to the formation of $\mathrm{Cu}_{3} \mathrm{~N}^{125}$ Molecules in red are the one detected by GC-MS.

The standard synthesis is performed at $140{ }^{\circ} \mathrm{C}$ under inert atmosphere, in a pressure tube. Over the course of the reaction, the color changes from dark blue to red. The average crystal size (determined from XRD) is quite insensitive to the reaction conditions $\left(80^{\circ} \mathrm{C}-180^{\circ} \mathrm{C}, 5-60 \mathrm{~min}\right)$ and varies from 1.8 to $2.8 \mathrm{~nm}$. The authors further suggested a precursor conversion mechanism by analyzing the reaction by-products with gas chromatography-mass spectrometry (GC-MS), see Fig. 15. In the first step, copper(II) methoxide oxidizes $\mathrm{BnNH}_{2}$ to benzenemethanimine and is reduced to $\mathrm{Cu}(\mathrm{I})$. This proposal is based on the detection of methanol in GC-MS. This reactivity is special for $\mathrm{Cu}(\mathrm{OMe})_{2}$ since other $\mathrm{Cu}$ (II) salts such as $\mathrm{Cu}(\mathrm{II})$ chloride make stable complexes with amines and fail to produce $\mathrm{Cu}_{3} \mathrm{~N}$. The benzenemethanimine intermediate reacts with benzylamine, yielding $N$-benzylidenebenzylamine (detected by GC-MS) and ammonia. The in situ formed ammonia reacts with $\mathrm{Cu}(\mathrm{OMe})$ to form $\mathrm{Cu}_{3} \mathrm{~N}$. Traces of benzonitrile are also observed at the GC, which is justified by further oxidation of benzenemethanimine in presence of $\mathrm{Cu}(\mathrm{II})$. This synthetic strategy was adopted by Liu and co-workers, but also requires a specific reagent purity and supplier. ${ }^{128}$

\section{3. $\mathrm{Cu}_{3} \mathrm{~N}$ nanocrystal synthesis via sol-gel chemistry}

In aqueous sol-gel chemistry, dissolved metal precursors are hydrolyzed with water and further condense in metal oxide particles and gels. ${ }^{129}$ Similarly, researchers have synthesized copper nitride NCs by aminolysis (reaction with ammonia) and condensation. In 2018, Egeberg et al. reacted CuI with ammonia under basic conditions to form $\mathrm{Cu}(\mathrm{NH})_{2} \cdot{ }^{126}$

$$
\mathrm{CuI} \underset{\text { pyridine },-35^{\circ} \mathrm{C}}{\stackrel{\mathrm{KNH}_{2} / \mathrm{lq}-\mathrm{NH}_{3}}{\longrightarrow}} \mathrm{Cu}\left(\mathrm{NH}_{2}\right) \underset{\text { pyridine }, 130^{\circ} \mathrm{C}}{\stackrel{\mathrm{NH}_{3} \uparrow}{\longrightarrow}} \mathrm{Cu}_{3} \mathrm{~N}
$$

By condensation of the copper amide under reflux conditions, small copper nitride NCs are obtained $(4.2 \pm 0.7 \mathrm{~nm})$, see Fig. 16. Only pyridine is observed at the surface of the NCs according to FT-IR and elemental analysis, which could explain why these NCs are air and moisture sensitive. 


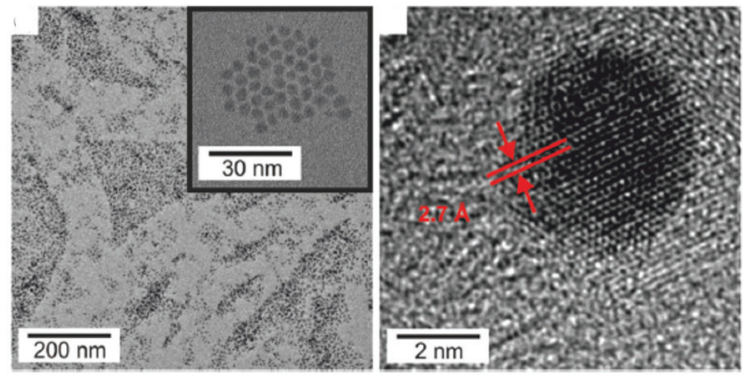

Fig. 16 TEM images of $\mathrm{Cu}_{3} \mathrm{~N}$ NCs synthesized by sol-gel chemistry according to ref. 126. Reproduced from ref. 126 with permission from the Royal Society of Chemistry.

Alternatively, Nakamura et al. have formed $\mathrm{Cu}_{3} \mathrm{~N}$ from copper(II) acetate in nonanol by bubbling ammonia through the mixture at $190{ }^{\circ} \mathrm{C}$ for $1 \mathrm{~h} .{ }^{123}$ The final NCs are not colloidally stable and form aggregates of about $200 \mathrm{~nm}$ with crystallite sizes of 20-30 $\mathrm{nm}$. The same colour changes are observed; from blue to yellow to dark brown. Single phase $\mathrm{CuO}$ is formed by using shorter chain alcohols such as pentanol, hexanol and heptanol at $130{ }^{\circ} \mathrm{C}$. With increasing temperature, an increasing amount of copper nitride is obtained and from $170{ }^{\circ} \mathrm{C}$ pure copper nitride is formed. The authors propose the following mechanism. First, ammonia forms a complex with $\mathrm{Cu}(\mathrm{II})$, evidenced by a color change from green to blue. Second, the authors hypothesize $\mathrm{Cu}$ (II) is reduced by nonanol. The color change to yellow is consistent with a $\mathrm{Cu}(\mathrm{I})$ species but the authors do not detect the direct product, nonyl aldehyde. They do detect 9-ODEamide, of which it is unclear how it is exactly formed. Finally, the $\mathrm{Cu}(\mathrm{I})$ species reacts with ammonia to form copper nitride. In the background, there is also the esterification of acetate with nonanol to nonyl acetate. According to the mechanism, a lot of protons are released but the authors did not try to uncover the fate of these protons. Nor were alternative hypotheses considered such as the reduction of $\mathrm{Cu}$ (II) by ammonia itself.

\subsection{Alternative precursors for $\mathrm{Cu}_{3} \mathrm{~N}$ nanocrystal synthesis}

In 2018, Mondal and co-workers obtained $\mathrm{Cu}_{3} \mathrm{~N}$ by reacting hexamethylenetetraamine (HMT) and $\mathrm{Cu}\left(\mathrm{NO}_{3}\right)_{2} \cdot 5 \mathrm{H}_{2} \mathrm{O}$ in $n$-hexanol at $200{ }^{\circ} \mathrm{C}$ for one hour under an inert atmosphere. $^{122}$ HMT undergoes hydrolysis and forms formaldehyde and $\mathrm{NH}_{3}$. The latter is the source of nitrogen as described in Fig. 17. Copper nitrate is in this case simply the source of water and $\mathrm{Cu}$ and not the nitrogen source. $\mathrm{Cu}(\mathrm{II})$ is assumed to be reduced by the formaldehyde intermediate, but the authors do not show evidence for the formation of formic acid. The final NCs are around $80 \mathrm{~nm}$ in size, which is most likely due to the absence of a strongly coordinating ligand.

Also in 2018, Sithole et al. synthesized a novel copper precursor: pyrrole-2-carbaldpropyliminato $\mathrm{Cu}(\mathrm{II})$ (PPC), see Fig. 18. ${ }^{124}$ PPC is synthesized from pyrrole-2-carboxaldehyde, copper acetate and propylamine in deionized water, filtered

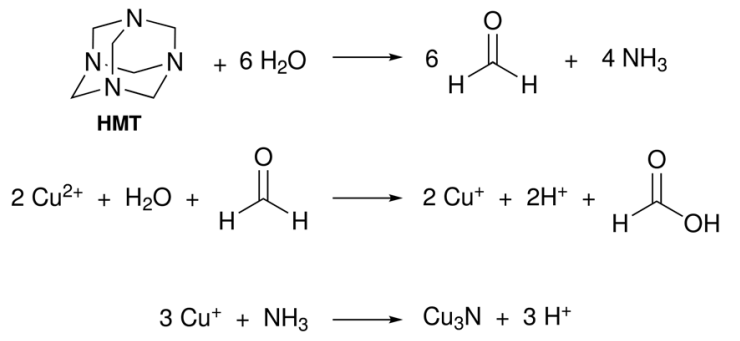

Fig. 17 Proposed reaction mechanism for $\mathrm{Cu}_{3} \mathrm{~N}$ formation from hexamethylenetetraamine and $\mathrm{Cu}\left(\mathrm{NO}_{3}\right)_{2} \cdot 5 \mathrm{H}_{2} \mathrm{O} .{ }^{122}$

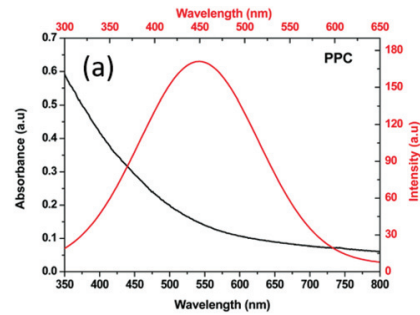

(c)

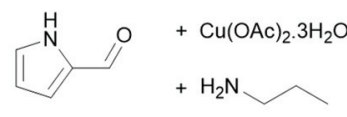

PPC + octadecylamine $\stackrel{260^{\circ} \mathrm{C}}{\longrightarrow}$
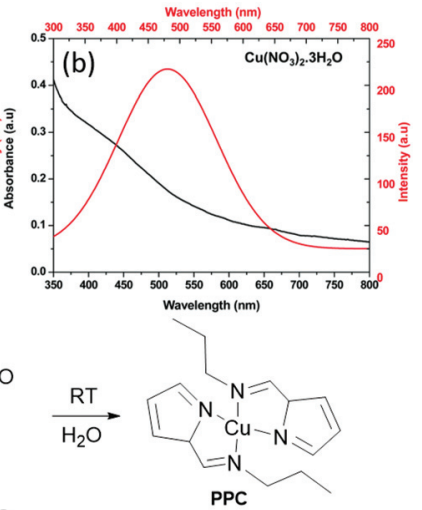

$\mathrm{Cu}_{3} \mathrm{~N}$
Fig. 18 UV-Vis absorption and photoluminescence spectra of $\mathrm{Cu}_{3} \mathrm{~N}$ obtained via (a) PPC and (b) $\mathrm{Cu}\left(\mathrm{NO}_{3}\right)_{2} \cdot 3 \mathrm{H}_{2} \mathrm{O}$ method. Reprinted from ref. 124 with permission from the Royal Society of Chemistry. (c) Reaction mechanism proposed for $\mathrm{Cu}_{3} \mathrm{~N}$ formation from the reaction of pyrrole-2carbaldpropyliminato $\mathrm{Cu}(\mathrm{II})$ (PPC) and ODA shown below. ${ }^{124}$

and recrystallized. In a second step, PPC is heated with ODA to form $\mathrm{Cu}_{3} \mathrm{~N}$ (Fig. 18). The resulting spherical NCs are about $1.5-4 \mathrm{~nm}$ in diameter, in contrast to the $18 \mathrm{~nm}$ cubes that are obtained with copper nitrate under identical conditions. The photoluminescence of the smaller $\mathrm{Cu}_{3} \mathrm{~N}$ NCs is slightly blueshifted to the emission of the larger NCs, which could possibly be ascribed to quantum confinement. Indeed, we estimated from the calculated dielectric constant and the effective hole and electron masses, an exciton Bohr radius of about $3 \mathrm{~nm}$. However, a direct relation between size and optical properties is currently missing.

\section{Zinc nitride}

$\mathrm{Zn}_{3} \mathrm{~N}_{2}$ has a cubic crystal structure ( $I a \overline{3}$ space group) with a lattice constant of $9.7691 \AA$ (Fig. 19). ${ }^{130}$ It is a nontoxic, earth-abundant, and low-cost semiconductor, ${ }^{131}$ and is therefore promising for various applications. However, it has been less exploited than other nitrides due to the difficulties in preparation and its high reactivity towards water. ${ }^{132}$ As a II-V semiconductor, $\mathrm{Zn}_{3} \mathrm{~N}_{2}$ has a high electron mobility and carrier concentration. The reported band gap for $\mathrm{Zn}_{3} \mathrm{~N}_{2}$ 
(a)
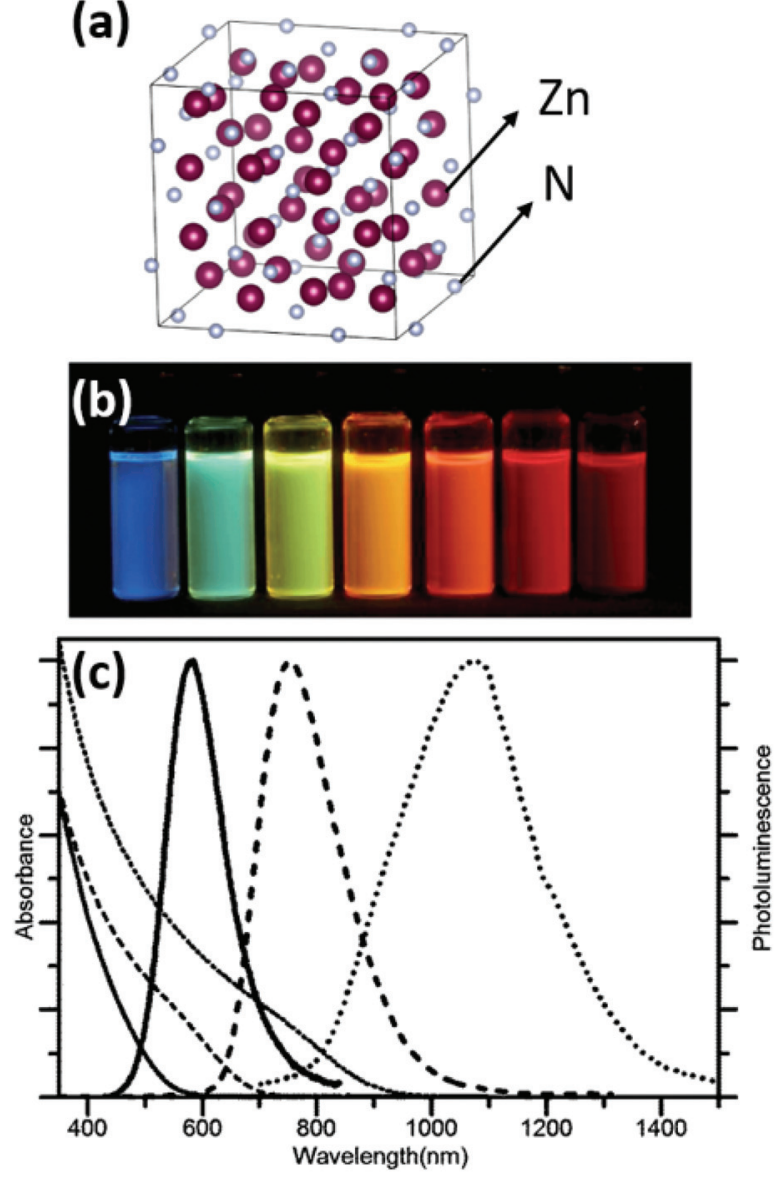

Fig. 19 (a) Crystal structure of $\mathrm{Zn}_{3} \mathrm{~N}_{2}$ metal nitride. The metal is represented in purple and the nitrogen atom in grey. Structures plotted using VESTA. ${ }^{48}$ Cif file obtained from ref. 130. (b) Toluene solutions of OLAm capped $\mathrm{Zn}_{3} \mathrm{~N}_{2} \mathrm{NCs}$ sampled at different reaction times and excited with a $365 \mathrm{~nm}$ lamp. (c) Absorption (thin lines) and emission (thick lines) spectra of $\mathrm{Zn}_{3} \mathrm{~N}_{2} \mathrm{NCs}$ with mean diameters of $2.1 \pm 0.4 \mathrm{~nm}$ (solid lines), $4.6 \pm 2.3 \mathrm{~nm}$ (dashed lines) and $7.1 \pm 2.0 \mathrm{~nm}$ (dotted lines). Reproduced from ref. 136 with permission from the Royal Society of Chemistry.

varies from 1.0 to $3.3 \mathrm{eV}$ depending on the preparation methods. ${ }^{133-135}$

Various physical methods or nitridation approaches have been employed to synthesize $\mathrm{Zn}_{3} \mathrm{~N}_{2}$ as thin films, ${ }^{137}$ powders, ${ }^{138}$ hollow balls, ${ }^{139}$ or nanowires. ${ }^{134}$ One chemical approach was reported by Taylor et al. where diethylzinc was reacted with an ammonia flow in ODE, with OLAm as the capping ligand.

$$
\mathrm{ZnEt}_{2}+\mathrm{NH}_{3} \underset{\text { ODE, OLAm }}{\stackrel{225^{\circ} \mathrm{C}}{\longrightarrow}} \mathrm{Zn}_{3} \mathrm{~N}_{2}
$$

The size is tuned by the stepwise addition of the diethylzinc precursor. Thus, NCs emitting in the range 500-1100 nm were obtained, ${ }^{140}$ with a photoluminescence quantum yield greater than $50 \%$. The authors further investigated the effect of the ratio between the diethylzinc to ammonia on the growth. A lower ammonia flow rate or higher diethylzinc injection promotes growth and large particles are obtained. Higher ammonia flow rates lead to smaller NCs. ${ }^{136}$

\section{Group 13 nitrides}

Among the group 13 nitrides, GaN has acquired most fame due to its use in blue LEDs, a feat that has been awarded with the 2014 nobel prize in Physics. ${ }^{141}$ The most stable phase of the group 13 nitrides has the wurtzite crystal structure. The bandgap of AlN, GaN and InN is $6.2 \mathrm{eV}, 3.4 \mathrm{eV}$ and $0.7 \mathrm{eV}$ respectively. As discussed before AlN is the least interesting. nitride of group 13 since it is considered a saline nitride and quickly reacts with water. However, aluminum nitride (AlN) has a high thermal conductivity (up to $320 \mathrm{~W} \mathrm{~m}^{-1} \mathrm{~K}^{-1}$ ), high acoustic wave velocity, and electrical resistance. ${ }^{142}$ These properties raise the potential of AlN for applications such as thermal interfaces for electronic laser, brackets for LED technology, resonators, sensors, actuators, etc. ${ }^{143-145}$ The different synthetic approaches for cubic AlN formation have been presented elsewhere. ${ }^{146}$

$\mathrm{GaN}$ and InN nanocrystals are considered the possible next generation of QDs. While the exciton Bohr radius of gallium nitride is $3.2 \mathrm{~nm}$, the exciton Bohr radius of indium nitride is $8 \mathrm{~nm}$. Together with the formation of solid solutions $\left(\operatorname{In}_{x} \mathrm{Ga}_{1-x} \mathrm{~N}\right)$, this provides ample opportunity to tune the optical properties using either quantum confinement or compositional control. GaN is being investigated for high frequency and high power transistor design. ${ }^{147,148} \mathrm{InN}$ is a promising compound for optoelectronic applications due to its low bandgap, small effective mass and efficient electron transport. InN is also considered for low-cost, high-efficiency solar cells, photomasks, laser diodes, sensors, and biological imaging. ${ }^{149-153}$ InN has a complex plasmonic behavior due to a nonparabolic dispersion of its conduction band. ${ }^{154,155}$

\subsection{Synthesis of group 13 nitride powders}

In 2004 , InN was prepared by the conversion of $\operatorname{In}_{2} \mathrm{O}_{3}$ under ammonia flow in a temperature range of $600{ }^{\circ} \mathrm{C}$ to $730{ }^{\circ} \mathrm{C}$. Depending on the temperature, either spherical NCs or hollow microtubes are formed. This is due to the decomposition of InN at a temperature around $650^{\circ} \mathrm{C}$ into metallic In and nitrogen $^{156}$

$$
\begin{gathered}
\operatorname{In}_{2} \mathrm{O}_{3}+2 \mathrm{NH}_{3} \rightarrow 2 \operatorname{InN}+3 \mathrm{H}_{2} \mathrm{O} \\
2 \operatorname{InN} \stackrel{650^{\circ} \mathrm{C}}{\longrightarrow} 2 \mathrm{In}+\mathrm{N}_{2}
\end{gathered}
$$

GaN NCs in a silica matrix were synthesized by first forming an oxide gel of gallium and silicon. The gel is then annealed at $900{ }^{\circ} \mathrm{C}$ for $5 \mathrm{~h}$ under $\mathrm{NH}_{3}$ atmosphere. ${ }^{157}$ Variations on this strategy exist where pure GaN nanocrystalline powders are formed by annealing $\mathrm{Ga}_{2} \mathrm{O}_{3}, \mathrm{GaO}(\mathrm{OH})$, or $\mathrm{NH}_{4}\left[\mathrm{Ga}(\mathrm{OH})_{2} \mathrm{CO}_{3}\right]$ under an $\mathrm{NH}_{3}$ atmosphere at 900-950 ${ }^{\circ} \mathrm{C} .{ }^{158-161}$ Similar to the case of TiN, the solid state reaction between $\mathrm{Ga}_{2} \mathrm{O}_{3}$ (or $\gamma-\mathrm{Al}_{2} \mathrm{O}_{3}$ ) and cyanamide $\mathrm{CN}_{2} \mathrm{H}_{2}$ 
yields GaN (or AlN) NCs. ${ }^{67,162}$ Finally, the urea glass route was also successful in synthesizing GaN nanopowders.

\subsection{Synthesis strategies based on azide or amide precursors}

Colloidally stable, but poorly crystalline GaN NCs are obtained by refluxing $\left[\mathrm{Et}_{2} \mathrm{Ga}\left(\mathrm{N}_{3}\right)\right]_{3},\left(\mathrm{~N}_{3}\right)_{2} \mathrm{Ga}\left[\left(\mathrm{CH}_{2}\right)_{3} \mathrm{NMe}_{2}\right]$, or $\left(\mathrm{Et}_{3} \mathrm{~N}\right) \mathrm{Ga}$ $\left(\mathrm{N}_{3}\right)_{3}$ in triglyme at $220{ }^{\circ} \mathrm{C}$ for 5 hours. ${ }^{163} \mathrm{Also} \mathrm{GaCl}_{3}$ and $\mathrm{NaN}_{3}$ react to form gallium azide, which forms amorphous $\mathrm{GaN}$ at $220{ }^{\circ} \mathrm{C}$ or $260{ }^{\circ} \mathrm{C}$ in $\mathrm{THF}$ or toluene respectively. Annealing and $\mathrm{NaCl}$ removal are necessary in order to form crystalline powders. ${ }^{164}$ Finally, crystalline GaN NCs were formed from $\mathrm{NaN}_{3}$ and metal Ga by heating to $700{ }^{\circ} \mathrm{C}$ under nitrogen in a high-pressure apparatus. ${ }^{165}$

Janik et al. formed GaN NCs via pyrolysis at $450-500{ }^{\circ} \mathrm{C}$ of a gallium imide $\left[\mathrm{Ga}(\mathrm{NH})_{3 / 2}\right]_{n}$ precursor (obtained by reaction of $\left[\mathrm{Ga}\left(\mathrm{NMe}_{2}\right)_{3}\right] 2$ and $\left.\mathrm{NH}_{3}\right) .{ }^{166}$ In 1999, this method was improved by crystallizing the $\left[\mathrm{Ga}(\mathrm{NH})_{3 / 2}\right]_{n}$ precursor in hot trioctylamine $\left(360{ }^{\circ} \mathrm{C}\right.$ for $24 \mathrm{~h}$ ) under a flow of ammonia. ${ }^{167}$ During cooldown of the reaction mixture, a solution of hexadecylamine in trioctylamine was added, which improved the colloidal stability of the final GaN NCs. These NCs have a diameter of $3 \mathrm{~nm}$ and feature a first exitonic emission at $3.65 \mathrm{eV}$, higher than the bulk bandgap of GaN.

$\beta$-GaN NPs of 3-8 $\mathrm{nm}$ in size were obtained via microwave heating of $\mathrm{Ga}\left(\mathrm{NH}_{2}\right)_{3}$ in ionic liquid at $300^{\circ} \mathrm{C}$ for $1 \mathrm{~h}$. The colorless suspension of $\mathrm{Ga}\left(\mathrm{NH}_{2}\right)_{3}$ was obtained by dissolving $\mathrm{GaCl}_{3}$ in liquid $\mathrm{NH}_{3}$ at $-35{ }^{\circ} \mathrm{C}$ and adding $\mathrm{KNH}_{2}$. The obtained NCs show a bandgap around $3.9 \mathrm{eV}$ which is $0.6 \mathrm{eV}$ above the $\beta$-GaN bulk bandgap. The authors attributed this blue shift to quantum confinement. The fluorescence properties of the assynthesized NCs are shown in Fig. $20{ }^{168}$

In 2006 Dingman et al. reported the synthesis of InN nanofibres at low temperatures $\left(203{ }^{\circ} \mathrm{C}\right)$, catalyzed by nanometer sized droplets of In metal (also called a solution-liquid-solid (SLS) mechanism). ${ }^{169}$ The authors prepared two different indium precursors $\left({ }^{\mathrm{i}} \mathrm{Pr}_{2} \mathrm{InN}_{3}\right.$ and ${ }^{t} \mathrm{Bu}_{2} \mathrm{InN}_{3}$ ) by reacting trialkylindium first with methanol and subsequently with trimethylsilylazide. Crystalline InN was then formed by reacting the as mentioned precursors with 1,1-dimethylhydrazine $\left(\mathrm{H}_{2} \mathrm{NNMe}_{2}\right)$ at $203{ }^{\circ} \mathrm{C}$ for $20 \mathrm{~h}$. The role of 1,1-dimethylhydrazine is to

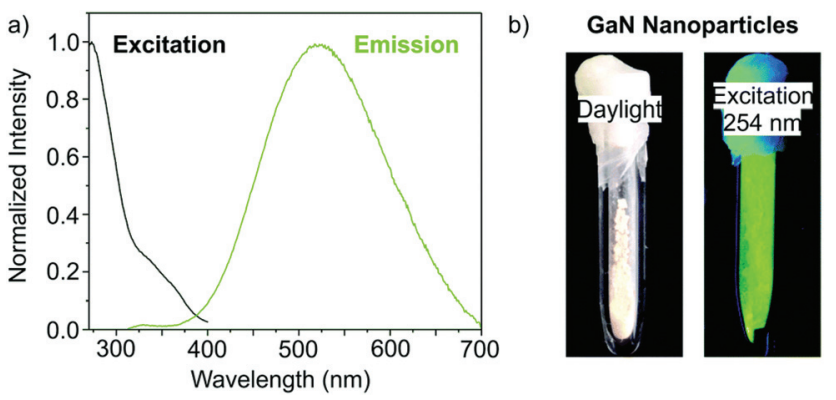

Fig. 20 (a) Emission spectrum at $274 \mathrm{~nm}$ and excitation spectrum at $523 \mathrm{~nm}$ of the synthesized GaN. (b) Photographs of the as synthesized GaN NCs in daylight and under excitation at $254 \mathrm{~nm}$. Reprinted from ref. 168 with permission from the Royal Society of Chemistry. reduce part of the indium precursors to In droplets, which then catalyze the InN crystallization.

$$
\begin{gathered}
\mathrm{R}_{3} \mathrm{In}+\mathrm{MeOH} \stackrel{\mathrm{RT}, 10 \mathrm{~min}}{\longrightarrow} \mathrm{R}_{2} \mathrm{InOMe}+\mathrm{RH} \\
\mathrm{R}_{2} \mathrm{InOMe}+\mathrm{TMSN}_{3} \stackrel{\mathrm{RT}, 210 \mathrm{~h}}{\longrightarrow} \mathrm{R}_{2} \mathrm{InN}_{3}+\mathrm{TMSOMe} \\
\mathrm{R}_{2} \mathrm{InN}_{3}+\mathrm{H}_{2} \mathrm{NNMe}_{2} \underset{20 \mathrm{~h}}{\stackrel{203^{\circ} \mathrm{C}}{\longrightarrow} \mathrm{InN}}
\end{gathered}
$$

In 2006 Choi et al. synthesized InN NCs from indium bromide and sodium azide under solvothermal conditions. ${ }^{170}$ The indium azide intermediate decomposes into InN and $\mathrm{N}_{2}$.

$$
\begin{gathered}
\operatorname{InBr}_{3}+3 \mathrm{NaN}_{3} \stackrel{280^{\circ} \mathrm{C}}{\longrightarrow}\left[\operatorname{In}\left(\mathrm{N}_{3}\right)_{3}\right]+3 \mathrm{NaBr} \\
{\left[\operatorname{In}\left(\mathrm{N}_{3}\right)_{3}\right] \stackrel{280^{\circ} \mathrm{C}}{\longrightarrow} \operatorname{InN}+4 \mathrm{~N}_{2}}
\end{gathered}
$$

The solvent used during the solvothermal treatment determines the final properties of the NCs. While toluene delivered $10 \mathrm{~nm}$ aggregated wurtzite InN, hexadecane yielded poorly crystalline InN. The reaction typically takes 3-5 days during which the reaction temperature was increased step by step to avoid explosive azide decomposition. Also $\operatorname{In}_{x} \mathrm{Ga}_{1-x} \mathrm{~N}$ alloyed particles were synthesized via this strategy. ${ }^{170}$

The reaction of potassium amide $\left(\mathrm{KNH}_{2}\right)$ and indium iodide in liquid ammonia yields an insoluble indium amide product. The latter is probably highly condensed, featuring imido bridges. Decomposition of this insoluble product at $400{ }^{\circ} \mathrm{C}$ under nitrogen atmosphere delivers $\mathrm{InN}$, In, $\mathrm{KNH}_{2}$, and $\mathrm{NH}_{3} \cdot{ }^{171}$ Alternatively, $\mathrm{InI}_{3}$ and $\mathrm{NaNH}_{2}$ were reacted in anhydrous benzene in a Teflon-lined pressure bomb. ${ }^{172}$ The crystallite size of the resulting InN NCs varies from $9.9 \pm 5 \mathrm{~nm}$ to $35.1 \pm 10 \mathrm{~nm}$ by increasing the reaction time or temperature. At ambient pressure, InN NCs (6.2 $\pm 2 \mathrm{~nm}$ diameter) have been synthesized using $\mathrm{InBr}_{3}$ and $\mathrm{NaNH}_{2}$ in hexadecane under an ammonia atmosphere.

$$
\mathrm{InBr}_{3}+3 \mathrm{NaNH}_{2} \underset{3 \mathrm{~h}}{\stackrel{250^{\circ} \mathrm{C}}{\longrightarrow}} \mathrm{InN}+\mathrm{In}
$$

A post-synthetic acid treatment (to remove $\operatorname{In}(0)$ ) and functionalization with OLAm yielded colloidally stable particles, see Fig. 21. ${ }^{173}$ This method has been further studied by Palomaki et al. where they use $\operatorname{In}_{2} \mathrm{~S}_{3}$ instead of $\mathrm{InBr}_{3}$ and ODE as their solvent. ${ }^{174}$

$$
\mathrm{In}_{2} \mathrm{~S}_{3}+\mathrm{NaNH}_{2} \underset{15 \min -12 \mathrm{~h}}{\stackrel{175-220^{\circ} \mathrm{C}}{\longrightarrow}} \operatorname{InN}+\text { In }
$$

To improve the size dispersion, size-selective precipitation was performed by the dropwise addition of acetonitrile to OLAm-capped InN NCs, and centrifugation. The final nanocrystal size was tuned from 4.5 to $9.9 \mathrm{~nm}$ by varying the reaction time from $15 \mathrm{~min}$ to $12 \mathrm{~h}$ at $220^{\circ} \mathrm{C}$. The NCs size also increases from 4.1 to $8.0 \mathrm{~nm}$ by increasing the reaction temperature from $175^{\circ} \mathrm{C}$ to $200{ }^{\circ} \mathrm{C}$ (at a fixed reaction time of three hours). Below $175^{\circ} \mathrm{C}$ no InN was formed.

When $\mathrm{InCl}_{3} \cdot 4 \mathrm{H}_{2} \mathrm{O}, \mathrm{NaNH}_{2}$, and sulfur were reacted in a pressure bomb at $160{ }^{\circ} \mathrm{C}$ for $30 \mathrm{~h}$, wurtzite InN crystals 


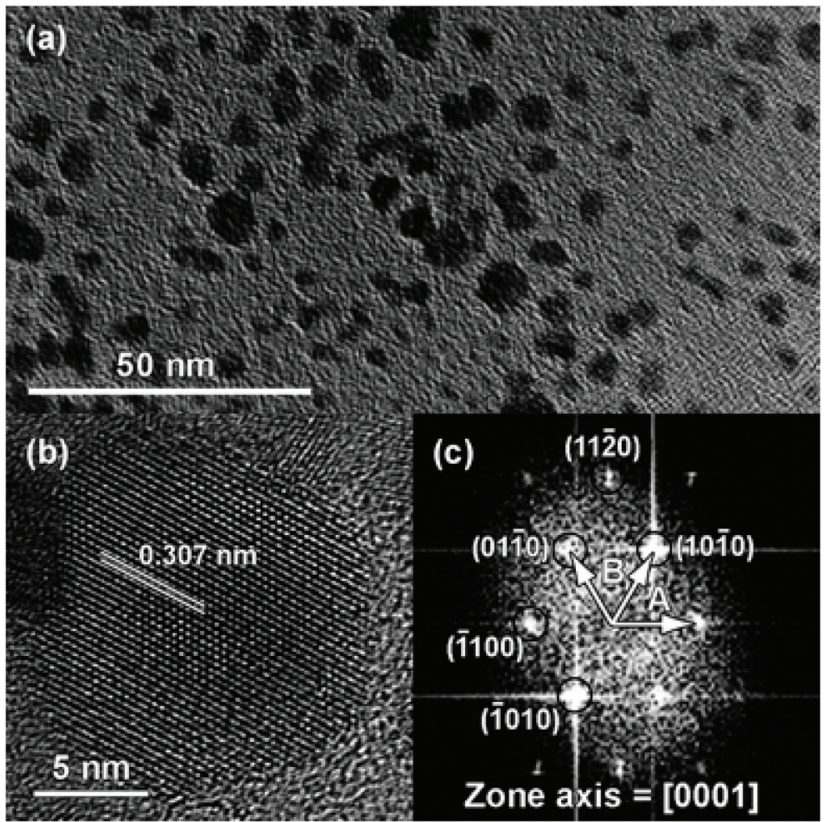

Fig. 21 TEM images of the colloidally stable $\ln \mathrm{N}$ obtained by Hsieh et al. after acid treatment. (a) Low magnification image, (b) high resolution image and (c) diffraction pattern obtained via fast Fourier transform (FFT). Reprinted with permission from ref. 173 with permission from the Royal Society of Chemistry.

(50-200 nm) were obtained. ${ }^{175}$ According to XRD, the reaction proceeds through a $\operatorname{In}_{2} \mathrm{~S}_{3}$ intermediate. Even larger particles $(500 \mathrm{~nm})$ were obtained using $\mathrm{In}\left(\mathrm{NO}_{3}\right)_{3} \cdot 5 \mathrm{H}_{2} \mathrm{O}$ as precursor.

\subsection{Colloidal InN NCs from lithium oleylamide}

Karan and coworked reported a surfactant-assisted procedure where all precursors are soluble. ${ }^{176} \mathrm{InBr}_{3}$ is first dissolved in a mixture of OLAm and ODE solvent (or hexadecane). At $220{ }^{\circ} \mathrm{C}$ the authors inject lithium oleylamide, which was synthesized from OLAm, n-butyllithium (n-BuLi) and tetramethylethylenediamine (TMEDA). After 10 minutes, the reaction is stopped and the product is purified. TEM analyis shows that the obtained particles consist of a $30 \mathrm{~nm} \operatorname{In}(0)$ core and $\mathrm{InN}$ outgrowths (Fig. 22). The mixed composition of In and InN is confirmed by XRD with sharp reflections for In and broader reflections for InN, consistent with their size difference (Fig. 22). Using the same strategy as mentioned before, In is removed by an nitric acid treatment and the InN NCs are stabilized by functionalization with OLAm. ${ }^{176}$

Intrigued by the high dissociation energy of $\mathrm{C}-\mathrm{N}$ bonds (330 $\left.\mathrm{kJ} \mathrm{mol}^{-1}\right)$, Beaulac et al. investigated the mechanism of this reaction by analyzing the by-products via ${ }^{1} \mathrm{H}$ NMR, ${ }^{13} \mathrm{C}$ NMR, 2D COSY NMR, and mass spectrometry. ${ }^{177}$ The authors propose that oleylamide is oxidized to oleylimine, thereby reducing $\operatorname{In}(\mathrm{III})$ to $\operatorname{In}(0)$, see Fig. 23. A second equivalent of oleylamide performs a nucleophilic attack on the imine, yielding a secondary aldimine and releasing $\mathrm{NH}_{2}{ }^{-}$. The latter goes on to react with In(III) to form InN. The proposed mechanism is based on the observation of secondary aldimine, ammonia,
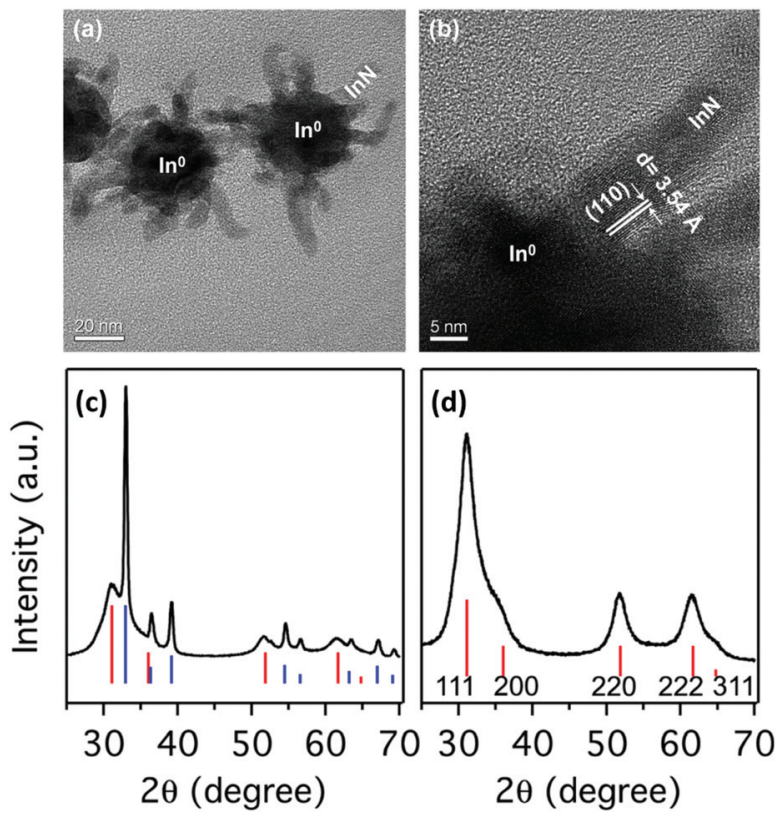

Fig. 22 TEM images of the NPs. (a) Overview of the as prepared sample, showing the $\ln N$ branches stemming out of larger $\ln (0)$ NPs. (b) HRTEM image of one of the $\operatorname{lnN}$ branches in (a) at the surface of the In (0) nanoparticle. XRD pattern for the (c) as-prepared sample and (d) acid treated sample. The vertical lines show the XRD patterns of bulk zinc blende- $\ln N$ (red) and tetragonal $\ln (0)$ (blue). Reprinted with permission from ref. 176. Copyright 2016 American Chemical Society.

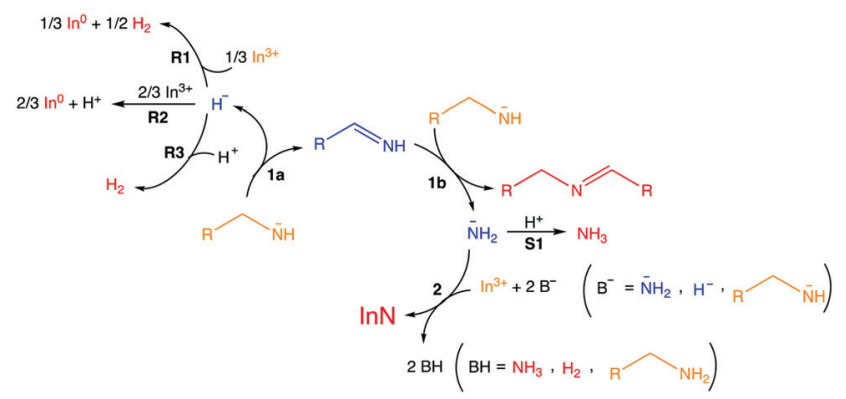

Fig. 23 Overall reaction. Reaction 1a, alkylamide precursor oxidation; reaction $1 b$, formation of the secondary imine leading to $\mathrm{NH}_{2}^{-}$production; reaction 2, nitride formation; R1, R2, R3, three hypothetical reduction processes concomitant with reaction $1 \mathrm{a} ; \mathrm{S} 1$, detrimental hypothetical side reaction. Orange, reactants; blue, intermediates (not isolated); red, identified products. Uncoordinated forms depicted here for simplicity. Reprinted with permission from ref. 177. Copyright 2018 American Chemical Society.

hydrogen, InN and In as reaction products. Oleylimine is too unstable to be isolated. $\operatorname{In}(0)$ is always formed in larger yields than InN, meaning that not all reactive $\mathrm{NH}_{2}{ }^{-}$are converted to InN.

\subsection{Other surfactant based strategies for colloidal nitrides}

$\mathrm{AlCl}_{3}, \mathrm{GaCl}_{3}$, and $\mathrm{InCl}_{3}$ react with urea to form the crystalline complexes: $\left[\mathrm{Al}\left(\mathrm{H}_{2} \mathrm{NCONH}_{2}\right)_{6}\right] \mathrm{Cl}_{3},\left[\mathrm{Ga}\left(\mathrm{H}_{2} \mathrm{NCONH}_{2}\right)_{6}\right] \mathrm{Cl}_{3}$, and [In $\left.\left(\mathrm{H}_{2} \mathrm{NCONH}_{2}\right)_{3} \mathrm{Cl}_{3}\right]{ }^{178}$ In the $\mathrm{Al}$ and $\mathrm{Ga}$ complexes, six urea 
molecules are coordinated to the metal and the chloride is simply the counter ion of the positively charged complex. In the In complex, three urea molecules and 3 chlorides build up the first coordination sphere. Pyrolysis of the complexes under nitrogen yields AlN, GaN or a mixture of $\mathrm{InN}$ and $\mathrm{In}_{2} \mathrm{O}_{3}$. Refluxing $\left[\mathrm{Ga}\left(\mathrm{H}_{2} \mathrm{NCONH}_{2}\right)_{6}\right] \mathrm{Cl}_{3}$ in trioctylamine $\left(365{ }^{\circ} \mathrm{C}\right)$ for 24 hours yields colloidal GaN NCs (2-3 nm). These particles show photoluminescence (PL) emission bands at 340 and $380 \mathrm{~nm}$. Refluxing the $\mathrm{Al}$ and In complex yields $\mathrm{AlN}$ and $\mathrm{InN}$ (with a minor indium oxide impurity) respectively. Later, the authors showed that the obtained GaN NCs were amorphous and further annealing in ammonia at $450{ }^{\circ} \mathrm{C}$ for $24 \mathrm{~h}$ was necessary to improve their crystallinity. ${ }^{179}$

In 2019, Chang Choi et al. designed a hot-injection strategy to obtain GaN QDs. ${ }^{180}$ Gallium chloride and stearic acid were dissolved in $\mathrm{ODE}$ and heated to $280{ }^{\circ} \mathrm{C}$ under argon. Subsequently, a solution of lithium bis(trimethylsilyl)amide in hexane was rapidly injected.

$$
\mathrm{GaCl}_{3}+\mathrm{LiN}(\mathrm{TMS})_{2} \underset{\text { ODE, stearic acid }}{\stackrel{220-280^{\circ} \mathrm{C}, 10-90 \mathrm{~min}}{\longrightarrow}} \mathrm{GaN}
$$

The nanocrystal size was hard to determine from TEM but surely below $5 \mathrm{~nm}$, which is also confirmed by the very broad nature of the XRD reflections. The PL emission of the QDS could be tuned from $315-355 \mathrm{~nm}$, while the bulk PL is at $365 \mathrm{~nm}$. Successful doping with zinc red-shifted the PL to $330-460 \mathrm{~nm}^{180}$

\section{Summary and outlook}

We have focused on precursor chemistry that allows synthesizing colloidal metal nitrides varying from plasmonic nitrides (Group 4) to semiconductors (Group 13). Approaches that lead to nanocrystal formation are described based on a systematic comparison between synthetic strategies. To date, the late transition metal and group 13 metal nitrides have been more extensively studied. While the reaction mechanism (precursor conversion) is most studied for the group 13 nitrides, the most uniform nanocrystals are obtained for $\mathrm{Cu}_{3} \mathrm{~N}$. At the same time, we were forced to conclude that there does not exist any convincing reports of a colloidal synthesis of group 4 and group 5 nitrides. Only nanopowders were succesfully obtained, of which some could be dispersed in water, albeit in aggregated form. It is striking that the ease of nitride formation seems to correlate with the valence of the elements. Whereas $\mathrm{Cu}^{+}$and $\mathrm{Ni}^{+}$easily crystallize as nitrides, $\mathrm{Ga}^{3+}$ and $\mathrm{In}^{3+}$ are more difficult to crystallize and the most successful approaches are based on crystallization, catalyzed by liquid nanodroplets of metal. An additional hurdle for the group 4 and 5 nitrides is the required reduction during the synthesis. For example, most common precursors for TiN and TaN are based on Ti(Iv) or $\mathrm{Ta}(\mathrm{v})$, while the final nitrides contain the metal in the + III oxidation state. To avoid the reduction step, future precursors of group 4 and 5 nitrides could start from the metal in the correct oxidation state. When designing new precursors, it is also useful to keep in mind the lessons from the metal chalcogenide field. The consensus seems to be that for optimal nanocrystal formation (and control over size), the conversion of precursor (P) to monomer (M) needs to be slow, relative to the crystallization (nucleation and growth) of the monomer into the final nanocrystals.

$$
\mathrm{P} \stackrel{\text { slow }}{\longrightarrow} \mathrm{M} \stackrel{\text { fast }}{\longrightarrow} \mathrm{NC}
$$

Since group 4 and 5 nitrides typically require high temperatures for crystallization, the logical conclusion is that their crystallization rate is low. Therefore, one should design nitride precursors that decompose even slower, or to apply strategies that enhance the rate of crystallization by lowering the barrier for bond forming and bond breaking. To move the field forward in a rational way, we need to understand the mechanism of the colloidal syntheses that do provide satisfactory results. While the precursor conversion has been studied for InN, there are many systems for which the mechanism is left unexplored. Even more problematic, the crystallization part of the mechanism has not been studied for any of the nitrides discussed here. However, the crystallization is likely the most difficult step in the whole process and thus the most critical to understand to make progress. Finally, it will be equally important that researchers treat colloidal synthesis as a true chemical reaction that has a chemical equation (which needs to be written down) and for which an accurate yield needs to be reported. By putting more rigor into writing the Experimental section, we can enhance the reproducibility of the field. Given the use of early transition metal nitrides for many applications such as catalysis, photothermal therapy, superconductors, and electrochemical capacitors, synthetic efforts should focus on providing these NCs as size-tunable colloidal particles. The field of colloidal metals nitrides is clearly challenging and still young, but adding colloidal nitrides (with synthetic control) to the portfolio of colloidal materials would open up many exciting possibilities for the future of materials science and nanotechnology.

\section{Conflicts of interest}

There are no conflicts to declare.

\section{Acknowledgements}

We acknowledge the University of Basel and the NCCR Molecular Systems Engineering (project number: 182895) for financial support. We thank Ajmal Roshan for help with the Table of Content graphic.

\section{References}

1 S. G. Kwon and T. Hyeon, Acc. Chem. Res., 2008, 41, 16961709. 
2 Z. Hens and J. De Roo, J. Am. Chem. Soc., 2020, 142, 15627-15637.

3 E. Matijevic, Chem. Mater., 1993, 5, 412-426.

4 Z. Hens, Science, 2015, 348, 1211-1212.

5 J. Park, J. Joo, S. Kwon, Y. Jang and T. Hyeon, Angew. Chem., Int. Ed., 2007, 46, 4630-4660.

6 I. Ojea-Jiménez, F. M. Romero, N. G. Bastús and V. Puntes, J. Phys. Chem. C, 2010, 114, 1800-1804.

7 R. Garcia-Rodriguez, M. P. Hendricks, B. M. Cossairt, H. T. Liu and J. S. Owen, Chem. Mater., 2013, 25, 12331249.

8 M. Niederberger and G. Garnweitner, Chem. - Eur. J., 2006, 12, 7282-7302.

9 M. D. Tessier, K. De Nolf, D. Dupont, D. Sinnaeve, J. De Roo and Z. Hens, J. Am. Chem. Soc., 2016, 138, 59235929.

10 M. A. Boles, D. Ling, T. Hyeon and D. V. Talapin, Nat. Mater., 2016, 15, 141-153.

11 N. C. Anderson, M. P. Hendricks, J. J. Choi and J. S. Owen, J. Am. Chem. Soc., 2013, 135, 18536-18548.

12 J. De Roo, F. Van den Broeck, K. De Keukeleere, J. C. Martins, I. Van Driessche and Z. Hens, J. Am. Chem. Soc., 2014, 136, 9650-9657.

13 F. W. Eagle, N. Park, M. Cash and B. M. Cossairt, ACS Energy Lett., 2021, 977-984.

14 J. De Roo, K. De Keukeleere, Z. Hens and I. Van Driessche, Dalton Trans., 2016, 45, 13277-13283.

15 Y. Yang, H. Qin and X. Peng, Nano Lett., 2016, 16, 21272132.

16 T. Kister, D. Monego, P. Mulvaney, A. Widmer-Cooper and T. Kraus, ACS Nano, 2018, 12, 5969-5977.

17 J. D. Martin, Chem. Mater., 2020, 32, 3651-3656.

18 R. G. Finke, M. A. Watzky and C. B. Whitehead, Chem. Mater., 2020, 32, 3657-3672.

19 V. K. Lamer and R. H. Dinegar, J. Am. Chem. Soc., 1950, 72, 4847-4854.

20 S. Özkar and R. G. Finke, J. Am. Chem. Soc., 2017, 139, 5444-5457.

21 S. Mozaffari, W. Li, C. Thompson, S. Ivanov, S. Seifert, B. Lee, L. Kovarik and A. M. Karim, Nanoscale, 2017, 9, 13772-13785.

22 B. M. McMurtry, K. Qian, J. K. Teglasi, A. K. Swarnakar, J. De Roo and J. S. Owen, Chem. Mater., 2020, 32, 43584368.

23 P. T. Prins, F. Montanarella, K. Dümbgen, Y. Justo, J. C. van der Bok, S. O. M. Hinterding, J. J. Geuchies, J. Maes, K. De Nolf, S. Deelen, H. Meijer, T. Zinn, A. V. Petukhov, F. T. Rabouw, C. De Mello Donega, D. Vanmaekelbergh and Z. Hens, Nano Lett., 2021, 21, 2487-2496.

24 S. Mozaffari, W. Li, M. Dixit, S. Seifert, B. Lee, L. Kovarik, G. Mpourmpakis and A. M. Karim, Nanoscale Adv., 2019, 1, 4052-4066.

25 D. R. Handwerk, P. D. Shipman, C. B. Whitehead, S. Özkar and R. G. Finke, J. Am. Chem. Soc., 2019, 141, 15827-15839.
26 M. P. Hendricks, M. P. Campos, G. T. Cleveland, I. J.-L. Plante and J. S. Owen, Science, 2015, 348, 1226-1230.

27 E. Dhaene, J. Billet, E. Bennett, I. Van Driessche and J. De Roo, Nano Lett., 2019, 19, 7411-7417.

28 K. De Keukeleere, S. Coucke, E. De Canck, P. Van Der Voort, F. Delpech, Y. Coppel, Z. Hens, I. Van Driessche, J. S. Owen and J. De Roo, Chem. Mater., 2017, 29, 1023310242.

29 D. Baranov, M. J. Lynch, A. C. Curtis, A. R. Carollo, C. R. Douglass, A. M. Mateo-Tejada and D. M. Jonas, Chem. Mater., 2019, 31, 1223-1230.

30 J. J. Calvin, J. K. Swabeck, A. B. Sedlak, Y. Kim, E. Jang and A. P. Alivisatos, J. Am. Chem. Soc., 2020, 142, 1889718906.

31 M. R. Friedfeld, J. L. Stein, A. Ritchhart and B. M. Cossairt, Acc. Chem. Res., 2018, 51, 2803-2810.

32 M. E. Mundy, D. Ung, N. L. Lai, E. P. Jahrman, G. T. Seidler and B. M. Cossairt, Chem. Mater., 2018, 30, 5373-5379.

33 A. G. Rachkov and A. M. Schimpf, Chem. Mater., 2021, 33, 1394-1406.

34 D. R. Sadoway, JOM, 1991, 43, 15-19.

35 A. MIURA, J. Ceram. Soc. Jpn., 2017, 125, 552-558.

36 K. Fung and G. Mantov, J. Electroanal. Chem. Interfacial Electrochem., 1972, 35, 27-34.

37 C. Housecroft, Inorganic Chemistry, Pearson, 2018, vol. 72, pp. 650-651.

38 S. H. Elder, F. J. DiSalvo, L. Topor and A. Navrotsky, Chem. Mater., 1993, 5, 1545-1553.

39 Y. Ma, L. Xiong, Y. Lu, W. Zhu, H. Zhao, Y. Yang, L. Mao and L. Yang, Front. Chem., 2021, 9, 390.

40 R. A. Karaballi, G. Humagain, B. R. A. Fleischman and M. Dasog, Angew. Chem., Int. Ed., 2019, 58, 3147-3150.

41 S. Ishii, R. P. Sugavaneshwar and T. Nagao, J. Phys. Chem. C, 2016, 120, 2343-2348.

42 E. Traver, R. A. Karaballi, Y. E. Monfared, H. Daurie, G. A. Gagnon and M. Dasog, ACS Appl. Nano Mater., 2020, 3, 2787-2794.

43 R. A. Karaballi, Y. E. Monfared and M. Dasog, Chemistry, 2020, 26, 8499-8505.

44 R. A. Karaballi, Y. Esfahani Monfared and M. Dasog, Langmuir, 2020, 36, 5058-5064.

45 U. Guler, S. Suslov, A. V. Kildishev, A. Boltasseva and V. M. Shalaev, Nanophotonics, 2015, 4, 269-276.

46 Y. Yuan, J. Wang, S. Adimi, H. Shen, T. Thomas, R. Ma, J. P. Attfield and M. Yang, Nat. Mater., 2019, 19, 282-286.

47 C. Defilippi, D. V. Shinde, Z. Dang, L. Manna, C. Hardacre, A. J. Greer, C. D’Agostino and C. Giordano, Angew. Chem., Int. Ed., 2019, 58, 15464-15470.

48 K. Momma and F. Izumi, J. Appl. Crystallogr., 2011, 44, 1272-1276.

49 A. N. Christensen, V. Romano, R. Hesse, A. F. Andresen and P. Fischer, Acta Chem. Scand., Ser. A, 1975, 29, 563564.

50 F. W. Glaser, D. Moskowitz and B. Post, JOM, 1953, 5, 1119-1120. 
51 K. Becker and F. Ebert, Z. Phys., 1925, 31, 268-272.

52 L. Hiltunen, M. Leskela, M. Makela, L. Niinisto, E. Nykanen and P. Soininen, Thin Solid Films, 1988, 166, 149-154.

53 A. Kafizas, C. J. Carmalt and I. P. Parkin, Coord. Chem. Rev., 2013, 257, 2073-2119.

54 A. Alvarez Barragan, N. V. Ilawe, L. Zhong, B. M. Wong and L. Mangolini, J. Phys. Chem. C, 2017, 121, 2316-2322.

55 K. S. Schramke, Y. X. Qin, J. T. Held, K. A. Mkhoyan and U. R. Kortshagen, ACS Appl. Nano Mater., 2018, 1, 28692876.

56 S. Exarhos, A. Alvarez-Barragan, E. Aytan, A. A. Balandin and L. Mangolini, ACS Energy Lett., 2018, 3, 2349-2356.

57 C. H. Winter, P. H. Sheridan, T. S. Lewkebandara, M. J. Heeg and J. W. Proscia, J. Am. Chem. Soc., 1992, 114, 1095-1097.

58 S. C. Dunn, A. S. Batsanov and P. Mountford, J. Chem. Soc., Chem. Commun., 1994, 2007-2008.

59 D. C. Bradley and I. M. Thomas, J. Chem. Soc., 1960, 38573861.

60 D. C. Bradley and E. G. Torrible, Can. J. Chem., 1963, 41, 134-138.

61 C. Lorber and L. Vendier, Dalton Trans., 2013, 42, 1220312219.

62 A. W. Jackson and A. L. Hector, J. Mater. Chem., 2007, 17, 1016-1022.

63 C. Lorber, R. Choukroun and L. Vendier, Eur. J. Inorg. Chem., 2006, 4503-4518.

64 N. Adams, H. R. Bigmore, T. L. Blundell, C. L. Boyd, S. R. Dubberley, A. J. Sealey, A. R. Cowley, M. E. G. Skinner and P. Mountford, Inorg. Chem., 2005, 44, 2882-2894.

65 A. Egeberg, O. Wenzel, R. Popescu, D. Gerthsen and C. Feldmann, ChemistryOpen, 2020, 10, 334-339.

66 A. Fischer, M. Antonietti and A. Thomas, Adv. Mater., 2007, 19, 264-267.

67 J. Buha, I. Djerdj, M. Antonietti and M. Niederberger, Chem. Mater., 2007, 19, 3499-3505.

68 Y. Liu, X. Zhang, L. Lu, J. Ye, J. Wang, X. Li, X. Bai and W. Wang, Chin. Chem. Lett., 2021, DOI: 10.1016/j.cclet. 2021.07.054.

69 C. Giordano, C. Erpen, W. T. Yao, B. Milke and M. Antonietti, Chem. Mater., 2009, 21, 5136-5144.

70 F. D. Qu, Y. Yuan and M. H. Yang, Chem. Mater., 2017, 29, 969-974.

71 G. S. Shanker, R. Bhosale, S. Ogale and A. Nag, Adv. Mater. Interfaces, 2018, 5, 1801488.

72 G. S. Shanker, G. B. Markad, M. Jagadeeswararao, U. Bansode and A. Nag, ACS Energy Lett., 2017, 2, 22512256.

73 D. B. O’Neill, S. K. Frehan, K. Zhu, E. Zoethout, G. Mul, E. C. Garnett, A. Huijser and S. H. C. Askes, Adv. Opt. Mater., 2021, 2100510.

74 X. Kan, J. Ding, H. Zhu, C. Deng and C. Yu, Powder Technol., 2017, 315, 81-86.

75 S. Hosoya, T. Yamagishi and M. Tokonami, J. Phys. Soc. Jpn., 1968, 24, 363-367.
76 J. Gatterer, G. Dufek, P. Ettmayer and R. Kieffer, Monatsh. Chem., 1975, 106, 1137-1147.

77 Y. Liu, Q. Wu, L. Liu, P. Manasa, L. Kang and F. Ran, J. Mater. Chem. A, 2020, 8, 8218-8233.

78 H. Cui, G. Zhu, X. Liu, F. Liu, Y. Xie, C. Yang, T. Lin, H. Gu and F. Huang, Adv. Sci., 2015, 2, 1500126.

79 Y. Li, J. Zhang, X. Qian, Y. Zhang, Y. Wang, R. Hu, C. Yao and J. Zhu, Appl. Surf. Sci., 2018, 427, 884-889.

80 D. Choi, G. Blomgren and P. Kumta, Adv. Mater., 2006, 18, 1178-1182.

81 T. Huang, S. Mao, G. Zhou, Z. Wen, X. Huang, S. Ci and J. Chen, Nanoscale, 2014, 6, 9608.

82 D. Choi and P. N. Kumta, J. Am. Ceram. Soc., 2011, 94, 2371-2378.

83 J. H. Swisher and M. H. Read, Metall. Trans., 1972, 3, 489.

84 L. Wang, X. Zhou, N. T. Nguyen, I. Hwang and P. Schmuki, Adv. Mater., 2016, 28, 2432-2438.

85 M. H. Tsai, S. C. Sun, H. T. Chiu, C. E. Tsai and S. H. Chuang, Appl. Phys. Lett., 1995, 67, 1128-1130.

86 Y.-J. Lee, D.-Y. Kim, K.-H. Lee, M.-H. Han, K.-S. Kang, K.-K. Bae and J.-H. Lee, Nanoscale Res. Lett., 2013, 8, 128.

87 C.-T. Ho, K.-B. Low, R. F. Klie, K. Maeda, K. Domen, R. J. Meyer and P. T. Snee, J. Phys. Chem. C, 2010, 115, 647-652.

88 C. F. Mallinson, B. M. Gray, A. L. Hector, M. A. McLachlan and J. R. Owen, Inorg. Chem., 2013, 52, 9994-9999.

89 A. Leineweber, H. Jacobs and S. Hull, Inorg. Chem., 2001, 40, 5818-5822.

90 F. Gillot, J. Oró-Solé and M. R. Palacín, J. Mater. Chem., 2011, 21, 9997.

91 D. C. Dunand and P. Müllner, Adv. Mater., 2010, 23, 216232.

92 N. Gajbhiye, R. Ningthoujam and J. Weissmller, Phys. Status Solidi A, 2002, 189, 691-695.

93 C. Bartholomew, J. Catal., 1976, 45, 41-53.

94 M. Shalom, V. Molinari, D. Esposito, G. Clavel, D. Ressnig, C. Giordano and M. Antonietti, Adv. Mater., 2013, 26, 1272-1276.

95 K. Xu, P. Chen, X. Li, Y. Tong, H. Ding, X. Wu, W. Chu, Z. Peng, C. Wu and Y. Xie, J. Am. Chem. Soc., 2015, 137, 4119-4125.

96 D. Gao, J. Zhang, T. Wang, W. Xiao, K. Tao, D. Xue and J. Ding, J. Mater. Chem. A, 2016, 4, 17363-17369.

97 G. S. Shanker and S. Ogale, ACS Appl. Energy Mater., 2021, 4, 2165-2173.

98 M. J. Winiarski, J. Solid State Chem., 2018, 266, 161-165.

99 D. Bocharov, A. Anspoks, J. Timoshenko, A. Kalinko, M. Krack and A. Kuzmin, Radiat. Phys. Chem., 2020, 175, 108100.

100 A. Zakutayev, C. M. Caskey, A. N. Fioretti, D. S. Ginley, J. Vidal, V. Stevanovic, E. Tea and S. Lany, J. Phys. Chem. Lett., 2014, 5, 1117-1125.

101 T. Maruyama and T. Morishita, Appl. Phys. Lett., 1996, 69, 890-891.

102 W. Zhu, X. Zhang, X. Fu, Y. Zhou, S. Luo and X. Wu, Phys. Status Solidi A, 2012, 209, 1996-2001. 
103 Z. Yin, C. Yu, Z. Zhao, X. Guo, M. Shen, N. Li, M. Muzzio, J. Li, H. Liu, H. Lin, J. Yin, G. Lu, D. Su and S. Sun, Nano Lett., 2019, 19, 8658-8663.

104 C. Panda, P. W. Menezes, M. Zheng, S. Orthmann and M. Driess, ACS Energy Lett., 2019, 4, 747-754.

105 P. X. Xi, Z. H. Xu, D. Q. Gao, F. J. Chen, D. S. Xue, C. L. Tao and Z. N. Chen, RSC Adv., 2014, 4, 14206-14209.

106 U. Hahn and W. Weber, Phys. Rev. B: Condens. Matter Mater. Phys., 1996, 53, 12684-12693.

107 F. Gulo, A. Simon, J. Kohler and R. K. Kremer, Angew. Chem., Int. Ed., 2004, 43, 2032-2034.

108 X. Y. Cui, A. Soon, A. E. Phillips, R. K. Zheng, Z. W. Liu, B. Delley, S. P. Ringer and C. Stampfl, J. Magn. Magn. Mater., 2012, 324, 3138-3143.

109 J. Choi and E. G. Gillan, Inorg. Chem., 2005, 44, 7385-7393.

110 M. Birkett, C. N. Savory, A. N. Fioretti, P. Thompson, C. A. Muryn, A. D. Weerakkody, I. Z. Mitrovic, S. Hall, R. Treharne, V. R. Dhanak, D. O. Scanlon, A. Zakutayev and T. D. Veal, Phys. Rev. B, 2017, 95, 115201.

111 U. Zachwieja and H. Jacobs, J. Less-Common Met., 1990, 161, 175-184.

112 H. Jacobs and U. Zachwieja, J. Less-Common Met., 1991, 170, 185-190.

113 R. Juza and H. Hahn, Z. Anorg. Allg. Chem., 1939, 241, 172-178.

114 G. Paniconi, Z. Stoeva, H. Doberstein, R. I. Smith, B. L. Gallagher and D. H. Gregory, Solid State Sci., 2007, 9, 907-913.

115 D. Wang and Y. Li, Chem. Commun., 2011, 47, 3604-3606.

116 D. Flaxbart, J. Am. Chem. Soc., 1999, 121, 2339-2339.

117 H. Wu and W. Chen, J. Am. Chem. Soc., 2011, 133, 1523615239.

118 D. D. Vaughn Ii, J. Araujo, P. Meduri, J. F. Callejas, M. A. Hickner and R. E. Schaak, Chem. Mater., 2014, 26, 6226-6232.

119 R. W. Lord, C. F. Holder, J. L. Fenton and R. E. Schaak, Chem. Mater., 2019, 31, 4605-4613.

120 D. Barman, S. Paul, S. Ghosh and S. K. De, ACS Appl. Nano Mater., 2019, 2, 5009-5019.

121 R. Kadzutu-Sithole, L. F. E. Machogo-Phao, T. Kolokoto, M. Zimuwandeyi, S. S. Gqoba, K. P. Mubiayi, M. J. Moloto, J. V. Wyk and N. Moloto, RSC Adv., 2020, 10, 34231-34246.

122 S. Mondal and C. R. Raj, J. Phys. Chem. C, 2018, 122, 18468-18475.

123 T. Nakamura, H. Hayashi, T. A. Hanaoka and T. Ebina, Inorg. Chem., 2014, 53, 710-715.

124 R. K. Sithole, L. F. E. Machogo, M. A. Airo, S. S. Gqoba, M. J. Moloto, P. Shumbula, J. Van Wyk and N. Moloto, New J. Chem., 2018, 42, 3042-3049.

125 R. Deshmukh, G. B. Zeng, E. Tervoort, M. Staniuk, D. Wood and M. Niederberger, Chem. Mater., 2015, 27, 8282-8288.

126 A. Egeberg, L. Warmuth, S. Riegsinger, D. Gerthsen and C. Feldmann, Chem. Commun., 2018, 54, 9957-9960.

127 R. Deshmukh, E. Tervoort, J. Kach, F. Rechberger and M. Niederberger, Dalton Trans., 2016, 45, 11616-11619.
128 Y. Liu, D. Lin, P. Y. Yuen, K. Liu, J. Xie, R. H. Dauskardt and Y. Cui, Adv. Mater., 2017, 29, 1605531.

129 J. Livage, C. Sanchez, M. Henry and S. Doeuff, Solid State Ionics, 1989, 32-33, 633-638.

130 D. Partin, D. Williams and M. O'Keeffe, J. Solid State Chem., 1997, 132, 56-59.

131 N. C. Coronel, Ph.D. thesis, 2016.

132 T. Yang, Z. Zhang, Y. Li, M. Lv, S. Song, Z. Wu, J. Yan and S. Han, Appl. Surf. Sci., 2009, 255, 3544-3547.

133 K. Kuriyama, Y. Takahashi and F. Sunohara, Phys. Rev. B: Condens. Matter Mater. Phys., 1993, 48, 2781-2782.

134 F. Zong, H. Ma, J. Ma, W. Du, X. Zhang, H. Xiao, F. Ji and C. Xue, Appl. Phys. Lett., 2005, 87, 233104.

135 S. Prabha, D. Durgalakshmi, K. Subramani, P. Aruna and S. Ganesan, ACS Appl. Mater. Interfaces, 2020, 12, 1924519257.

136 P. N. Taylor, M. A. Schreuder, T. M. Smeeton, A. J. D. Grundy, J. A. R. Dimmock, S. E. Hooper, J. Heffernan and M. Kauer, J. Mater. Chem. C, 2014, 2, 4379-4382.

137 A. H. Jayatissa, T. Wen and M. Gautam, J. Phys. D: Appl. Phys., 2012, 45, 045402.

138 G. Paniconi, Z. Stoeva, R. I. Smith, P. C. Dippo, B. L. Gallagher and D. H. Gregory, J. Solid State Chem., 2008, 181, 158-165.

139 F. Zong, H. Ma, C. Xue, W. Du, X. Zhang, H. Xiao, J. Ma and F. Ji, Mater. Lett., 2006, 60, 905-908.

140 R. Ahumada-Lazo, S. M. Fairclough, S. J. O. Hardman, P. N. Taylor, M. Green, S. J. Haigh, R. Saran, R. J. Curry and D. J. Binks, ACS Appl. Nano Mater., 2019, 2, 72147219.

141 H. Amano, N. Sawaki, I. Akasaki and Y. Toyoda, Appl. Phys. Lett., 1986, 48, 353-355.

142 M. Kaur, K. Singh, P. Singh, A. Kaur, R. Meena, G. P. Singh, H. Barabadi, M. Saravanan and A. Kumar, Nanomed. J., 2020, 7, 194-198.

143 Y. Bian, M. Liu, G. Ke, Y. Chen, J. DiBattista, E. Chan and Y. Yang, Surf. Coat. Technol., 2015, 267, 65-69.

144 C. Li, X. Liu, L. Shu and Y. Li, Mater. Express, 2015, 5, 367-370.

145 C. Li, X.-Z. Liu, B. Peng, L. Shu and Y.-R. Li, Rare Met., 2016, 35, 408-411.

146 V. Kudyakova, R. Shishkin, A. Elagin, M. Baranov and A. Beketov, J. Eur. Ceram. Soc., 2017, 37, 1143-1156.

147 G. G. Arizaga, M. J. Oviedo and O. E. Lopez, Colloids Surf., $B, 2012$, 98, 63-71.

148 P. Antoniammal and D. Arivuoli, J. Nanomater., 2012, 2012, 1-11.

149 S. Nakamura and G. Fasol, The Blue Laser Diode, Springer Berlin Heidelberg, 1997, pp. 313-315.

150 E. Starikov, P. Shiktorov, V. Gružinskis, L. Reggiani, L. Varani, J. Vaissière and J. H. Zhao, Phys. B, 2002, 314, 171-175.

151 H. Neff, O. Semchinova, A. Lima, A. Filimonov and G. Holzhueter, Sol. Energy Mater. Sol. Cells, 2006, 90, 982-997. 
152 H. P. T. Nguyen, Y.-L. Chang, I. Shih and Z. Mi, IEEE J. Sel. Top. Quantum Electron., 2011, 17, 1062-1069.

153 J. Wu, J. Appl. Phys., 2009, 106, 011101.

154 Z. H. Liu and R. Beaulac, Chem. Mater., 2017, 29, 7507-7514.

155 Z. Liu, L. M. Janes, M. Saniepay and R. Beaulac, Chem. Mater., 2018, 30, 5435-5443.

156 B. Schwenzer, L. Loeffler, R. Seshadri, S. Keller, F. F. Lange, S. P. DenBaars and U. K. Mishra, J. Mater. Chem., 2004, 14, 637.

157 G. Sinha, S. K. Panda, P. Mishra, D. Ganguli and S. Chaudhuri, J. Phys.: Condens. Matter, 2007, 19, 346209.

158 Y. Chen, N. Jyoti and J. Kim, Appl. Phys. A, 2010, 102, 517519.

159 Y. Chen, M. Maniruzzaman and J. Kim, Int. J. Precis. Eng. Manuf., 2011, 12, 573-576.

160 H. Xiao, H. Pei, J. Liu, J. Cui, B. Jiang, Q. Hou and W. Hu, Mater. Lett., 2012, 71, 145-147.

161 H. Yan, K. Liu, R. Luo, S. Chen and H. Cao, Mater. Lett., 2010, 64, 2109-2111.

162 P. G. Li, M. Lei, Y. X. Du, X. Guo and W. H. Tang, Appl. Surf. Sci., 2009, 255, 3843-3847.

163 A. Manz, A. Birkner, M. Kolbe and R. A. Fischer, Adv. Mater., 2000, 12, 569-573.

164 L. Grocholl, J. J. Wang and E. G. Gillan, Chem. Mater., 2001, 13, 4290-4296.

165 F. Kawamura, K. Watanabe, T. Takeda and T. Taniguchi, J. Cryst. Growth, 2011, 321, 100-105.

166 J. F. Janik and R. L. Wells, Chem. Mater., 1996, 8, 2708-2711.
167 O. I. Micic, S. P. Ahrenkiel, D. Bertram and A. J. Nozik, Appl. Phys. Lett., 1999, 75, 478-480.

168 H. F. Gaiser, R. Popescu, D. Gerthsen and C. Feldmann, Chem. Commun., 2020, 56, 2312-2315.

169 S. D. Dingman, N. P. Rath, P. D. Markowitz, P. C. Gibbons and W. E. Buhro, Angew. Chem., Int. Ed., 2000, 39, 14701472.

170 J. Choi and E. G. Gillan, J. Mater. Chem., 2006, 16, 37743784.

171 A. P. Purdy, Inorg. Chem., 1994, 33, 282-286.

172 C. Wu, T. Li, L. Lei, S. Hu, Y. Liu and Y. Xie, New J. Chem., 2005, 29, 1610.

173 J. C. Hsieh, D. S. Yun, E. Hu and A. M. Belcher, J. Mater. Chem., 2010, 20, 1435.

174 P. K. Palomaki, E. M. Miller and N. R. Neale, J. Am. Chem. Soc., 2013, 135, 14142-14150.

175 L. Wang, Q. Shen, D. Zhao, J. Lu, W. Liu, J. Zhang, K. Bao and Q. Zhou, J. Cryst. Growth, 2017, 471, 62-65.

176 N. S. Karan, Y. Chen, Z. Liu and R. Beaulac, Chem. Mater., 2016, 28, 5601-5605.

177 Y. Chen, N. T. Landes, D. J. Little and R. Beaulac, J. Am. Chem. Soc., 2018, 140, 10421-10424.

178 K. Sardar, M. Dan, B. Schwenzer and C. N. R. Rao, J. Mater. Chem., 2005, 15, 2175-2177.

179 B. Chitara, D. J. Late, S. B. Krupanidhi and C. N. R. Rao, Solid State Commun., 2010, 150, 2053-2056.

180 Y. C. Choi, H. Kim, C. Lee, J. Son, H. Baik, S. Park, J. Kim and K. S. Jeong, Chem. Mater., 2019, 31, 5370-5375. 